\title{
Radiocarbon and geologic evidence reveal Ilopango volcano as source of the colossal 'mystery' eruption of 539/40 CE
}

\author{
Robert A. Dull ${ }^{\text {a, b, *, John R. Southon }}{ }^{\text {c }}$, Steffen Kutterolf ${ }^{\text {d }}$, Kevin J. Anchukaitis ${ }^{\text {e }}$, Armin Freundt ${ }^{\text {, }}$, \\ David B. Wahl ${ }^{\text {f, g }}$, Payson Sheets ${ }^{\text {h }}$, Paul Amaroli ${ }^{i}$, Walter Hernandez ${ }^{j}$, Michael C. Wiemann ${ }^{k}$, Clive Oppenheimer ${ }^{1}$ \\ a Department of Earth and Environmental Sciences, California Lutheran University, Thousand Oaks, CA, 91360, USA \\ ${ }^{\mathrm{b}}$ Environmental Science Institute, University of Texas, Austin, TX, 78712, USA \\ ${ }^{c}$ Department of Earth System Science, University of California at Irvine, Irvine, CA, 92697, USA \\ d GEOMAR, Helmholtz Center for Ocean Research, Wischhofstr. 1-3, D-24148, Kiel, Germany \\ e School of Geography and Development and Laboratory of Tree-Ring Research, University of Arizona, Tucson, AZ, 85721, USA \\ ${ }^{\mathrm{f}}$ United States Geological Survey, Menlo Park, CA, 94025, USA \\ g Department of Geography, University of California at Berkeley, CA, 94720, USA \\ ${ }^{\mathrm{h}}$ Department of Anthropology, University of Colorado, Boulder, CO, 80309, USA \\ ${ }^{i}$ Fundación Nacional de Arqueología de El Salvador, FUNDAR, San Salvador, El Salvador \\ j Retired from Ministerio de Medio Ambiente y Recursos Naturales, San Salvador, El Salvador \\ ${ }^{\mathrm{k}}$ United States Department of Agriculture Forest Products Laboratory, Madison, WI, 53726, USA \\ ${ }^{1}$ Department of Geography, University of Cambridge, Downing Place, Cambridge, CB2 3EN, UK
}

\section{A R T I C L E IN F O}

Article history:

Received 24 February 2019

Received in revised form 19 July 2019

Accepted 22 July 2019

Available online $\mathrm{xxx}$

Keywords:

Holocene

Sixth century

Climate dynamics

Global

Central America

Tree rings

Volcanology

Radiocarbon

Maya

Classic period

\section{A B S T R A C T}

Ilopango volcano (El Salvador) erupted violently during the Maya Classic Period (250-900 CE) in a densely-populated and intensively-cultivated region of the southern Maya realm, causing regional abandonment of an area covering more than $20,000 \mathrm{~km}^{2}$. However, neither the regional nor global impacts of the Tierra Blanca Joven (TBJ) eruption in Mesoamerica have been well appraised due to limitations in available volcanological, chronological, and archaeological observations. Here we present new evidence of the age, magnitude and sulfur release of the TBJ eruption, establishing it as one of the two hitherto unidentified volcanic triggers of a period of stratospheric aerosol loading that profoundly impacted Northern Hemisphere climate and society between circa 536 and $550 \mathrm{CE}$. Our chronology is derived from 100 new radiocarbon measurements performed on three subfossil tree trunks enveloped in proximal TBJ pyroclastic deposits. We also reassess the eruption magnitude using terrestrial (El Salvador, Guatemala, Honduras) and near-shore marine TBJ tephra deposit thickness measurements. Together, our new constraints on the age, eruption size $\left(43.6 \mathrm{~km}^{3}\right.$ Dense Rock Equivalent of magma, magnitude $=7.0)$ and sulfur yield $(\sim 9-90 \mathrm{Tg})$, along with Ilopango's latitude $\left(13.7^{\circ} \mathrm{N}\right)$, squarely frame the TBJ as the major climate-forcing eruption of 539 or $540 \mathrm{CE}$ identified in bipolar ice cores and sourced to the tropics. In addition to deepening appreciation of the TBJ eruption's impacts in Mesoamerica, linking it to the major Northern Hemisphere climatic downturn of the mid-6th century $\mathrm{CE}$ offers another piece in the puzzle of understanding Eurasian history of the period.

(C) 2019

\section{Introduction and aims}

Other than geologically rare bolide impact events, explosive volcanic eruptions have the greatest capacity to impact human populations worldwide via climate forcing due to stratospheric aerosol loading (Rampino et al., 1988; Robock, 2002; Self, 2006). The climate impacts of major historical eruptions such as that of the 1815 Tambora and 1991 Pinatubo events have received particular attention since the volcano protagonists are known (Oppenheimer, 2003; Stothers, 1984a); still other major climate forcing eruptions such as the 1257 CE eruption of Samalas have only recently been revealed (Alloway et al., 2017; Lavigne et al., 2013). One of the largest and most persistent

\footnotetext{
* Corresponding author. Department of Earth and Environmental Sciences, California Lutheran University, 60 W Olsen Rd, Thousand Oaks, CA, 91360, USA.

Email address: robertdull@callutheran.edu (R.A. Dull)
}

atmospheric loading events in recorded history (Rampino et al., 1988) commenced in $536 \mathrm{CE}$ when stratospheric volcanic aerosol enveloped the Northern Hemisphere, initially for $\sim 18$ months (Arjava, 2005; Baillie, 1994, 2008; Gunn, 2000; Keys, 2000; Stothers, 1984a), followed by a second climatically-significant eruption occurring in 539 or 540 CE (Gautier et al., 2019; Sigl et al., 2015). The two eruptions initiated a pronounced short-term cooling that lasted at least until ca. $550 \mathrm{CE}$, as evidenced in tree ring records from Eurasia and North America (Baillie, 1994, 1999; Büntgen et al., 2016; Ferris et al., 2011; Gill, 2000; Larsen et al., 2008). Unseasonably cold summer temperatures, drought, crop failures and famine devastated societies from China to the Mediterranean to Mesoamerica for more than a decade, and may have facilitated a concurrent major outbreak of bubonic plague in the Byzantine Empire and demographic contraction in several regions of the world (Arjava, 2005; Baillie, 1994, 1999; Harper, 2017; Keys, 2000; Moreland, 2018; Oppenheimer, 
2011; Stothers, 1984b). A more protracted period of Northern Hemisphere continental cooling from 536 to $660 \mathrm{CE}$ has been dubbed, "the Late Antique Little Ice Age." (Büntgen et al., 2016).

Identifying the source(s) of the 'mystery cloud of 536 C.E.' (Stothers, 1984b) and the cooling that followed has been hindered by inconsistent dating of ice core records from Antarctica and Greenland and our limited knowledge of global volcanism in this time frame. Although these events were initially thought to have been caused by a single volcanic eruption (Keys, 2000; Stothers, 1984b), a lack of agreement between sulfate deposition records from the Greenland and Antarctic ice cores led to speculation that a comet impact was a more likely explanation (Baillie, 1994, 1999; Rigby et al., 2004), despite evidence for a volcanic sulfate peak in Antarctica dating to $540 \mathrm{CE}$ (Hammer et al., 1980). Ice core dating discrepancies between records from Antarctica (DML 05, DML 07, SPO4) and Greenland (Dye-3, GRIP, NGRIP) have since been resolved (Larsen et al., 2008; Sigl et al., 2015), and volcanic sulfate anomalies in 536 and $540 \mathrm{CE}$ now implicate two separate eruptions as the primary drivers of the global cooling: one occurring in 535 or $536 \mathrm{CE}$ and the second in 539 or 540 CE (Ferris et al., 2011; Larsen et al., 2008; Sigl et al., 2015; Stoffel et al., 2015). The bipolar ice core records suggest an extratropical Northern Hemisphere volcano was responsible for the first event, and a tropical volcano for the second (Sigl et al., 2015). Irradiance anomalies recorded in Scandinavian subfossil tree rings show pronounced negative excursions from the mean in 536 CE and in 541-544 CE (Helama et al., 2018), while polar ice core sulfate records suggest that the global aerosol loading resulting from the 539-540 CE eruption was higher than that produced by the 1815 eruption of Tambora (Sigl et al., 2015), resulting in summer temperatures $1.4-2.7^{\circ} \mathrm{C}$ cooler in Europe by $541 \mathrm{CE}$ (Sigl et al., 2015; Toohey et al., 2016). Anomalously cold summer temperatures persisted in much of the Northern Hemisphere throughout the 540s (Büntgen et al., 2016; Helama et al., 2018; Sigl et al., 2015) and to a lesser degree- possibly sustained via ocean and sea ice feedbacks - until circa 660 CE (Büntgen et al., 2016).

Several tropical volcanoes have been proposed as candidate sources for the 'mystery cloud' and the 536 and 540 CE ice core sulfate anomalies, most notably Rabaul, Papua New Guinea (Stothers, 1984b); El Chichón, Mexico (Gill, 2000; Nooren et al., 2009, 2017); and an unmapped submerged volcano in the Sunda Strait near Krakatau, Indonesia (Keys, 2000). The Rabaul and the Sunda Strait volcanoes can now be ruled out as candidates for the 535-540 CE eruptions because the radiocarbon, geochemical and volcanological evidence does not support such claims. The Rabaul eruption occurred circa 667-699 CE (McKee et al., 2015) and there are no significant Krakatau tephra dating from the 6th century (Southon et al., 2013). Similarly, the case for El Chichón is not compelling, since the local stratigraphic evidence points only to modest-sized eruptions: Volcanic Explosivity Index $(\mathrm{VEI})<4$ in the pertinent time frame (Espíndola et al., 2000; Macías et al., 2008; Nooren et al., 2017). Most Earth systems model simulations have suggested a Northern Hemisphere tropical source for the circa $540 \mathrm{CE}$ eruption, with some authors estimating that the best agreement with ice core sulfate records is with a volcano located around $15^{\circ} \mathrm{N}$ latitude (Toohey et al., 2016).

Located at $13.68^{\circ} \mathrm{N}$ latitude, some $15 \mathrm{~km}$ east of San Salvador, Ilopango caldera is a now-dormant volcano within the Central American Volcanic Arc (CAVA), which stretches $\sim 1100 \mathrm{~km}$ from Guatemala to Panama (Rose et al., 1999) (Fig. 1). Ilopango, which last erupted in 1880 CE (Williams and Meyer-Abich, 1955), and which has a long history of large magnitide explosive volcanism (Pedrazzi et al., 2019; Suñe-Puchol et al., 2019) was the source of several major (VEI 6+) Quaternary caldera-forming eruptions (Kutterolf et al., 2008; Rose et al., 1999; Suñe-Puchol et al., 2019; Williams and Meyer-Abich, 1955), including the late Holocene Tierra Blanca Joven (TBJ) event, the largest eruption in Central America since the Los Chocoyos eruption of Atitlán caldera (Guatemala) approximately 84 kyr ago (Kutterolf et al., 2008; Pedrazzi et al., 2019). The TBJ eruption has also been suggested as origin of the $536 \mathrm{CE}$ event in disparate sources (Barras, 2014; Breeze, 2016; Dull et al., 2010; Tvauri, 2014), but the challenges posed by the radiocarbon correction curve in this time frame and of precisely dating tropical trees have hitherto hampered negation or validation of this claim. The first conventional radiocarbon dating of samples associated with the TBJ eruption returned an average ${ }^{14} \mathrm{C}$ age of $1708 \pm 114 \mathrm{BP}$ (260 \pm 114 cal yr CE) (Sheets, 1983), but subsequent AMS radiocarbon dating of numerous individual plants killed by the eruption produced a tight cluster of ${ }^{14} \mathrm{C}$ ages around $1600{ }^{14} \mathrm{C}$ years BP (Dull et al., 2001). However, these dates still fall within a plateau on the ${ }^{14} \mathrm{C}$ calibration curve between ca. 420 and $540 \mathrm{CE}$, leading to large ( 120 yr) uncertainties in calibrated calendar ages even for precision AMS dates.

More generally, the potentially global significance of the TBJ eruption has been previously overlooked (Oppenheimer, 2011) due to uncertainties in its magnitude (Hart and Steen-McIntyre, 1983; Kutterolf et al., 2008; Pedrazzi et al., 2019) and timing (Dull et al., 2001, 2010; Sheets, 1983). The focus of efforts has rather been on the regional impacts of the TBJ eruption: areas in central and western El Salvador that were severely and directly affected by pyroclastic flows and tephra fallout (Dull, 2004; Dull et al., 2001; Hart and Steen-McIntyre, 1983; Sheets, 1983). Here, we revisit the questions of the age and size of the TBJ eruption drawing on new and extensive radiocarbon and stratigraphic evidence. In particular, we move beyond the limitations of single sample ${ }^{14} \mathrm{C}$ determinations and the 5 th-6th century radiocarbon plateau by sequential radiocarbon assays from the trunks of mature trees found embedded in the TBJ tephra deposits and Bayesian modeling techniques. This yields much tighter chronological constraints for the event, leading to a reassessment of the eruption's regional and global impacts in the light also of the most recently published bi-polar ice core records of global volcanism.

\section{Materials and methods}

\subsection{Field sampling}

Our new radiocarbon measurements are made on three tree trunks recovered from TBJ deposits. The sampling site of El Mico is located $2 \mathrm{~km}$ NNW of the town of Guazapa, El Salvador just above the modern Rio Guazapa floodplain (Fig. 2). This location is approximately $15 \mathrm{~km}$ north of the Ilopango caldera (Fig. 1). The site had previously been used as a quarry for TBJ tephra, which has been exploited in recent years for road fill and other purposes. Indications are that at least $5 \mathrm{~m}$ depth of the TBJ deposit had previously been excavated from this area, as attested by a remaining intact deposit $\sim 5 \mathrm{~m}$ immediately to the east of the El Mico-A tree trunk. In June 2012, a reconnaissance was made of the area, where numerous partially-carbonized and uncharred wood samples were located both in situ in the TBJ tephra deposit and on the ground surface exposed by quarry operations and subsequent erosion. Two large, well-preserved, unburnt trees were found. El Mico-A (76 cm diameter) was discovered on the western edge of the quarry trench (apparently) rooted in place, still vertical with TBJ tephra remaining intact on one side of the tree trunk (Fig. 2A-C). El Mico-B ( $38 \mathrm{~cm}$ diameter) was discovered in a horizontal position, but with its root ball intact, suggesting that it had either 


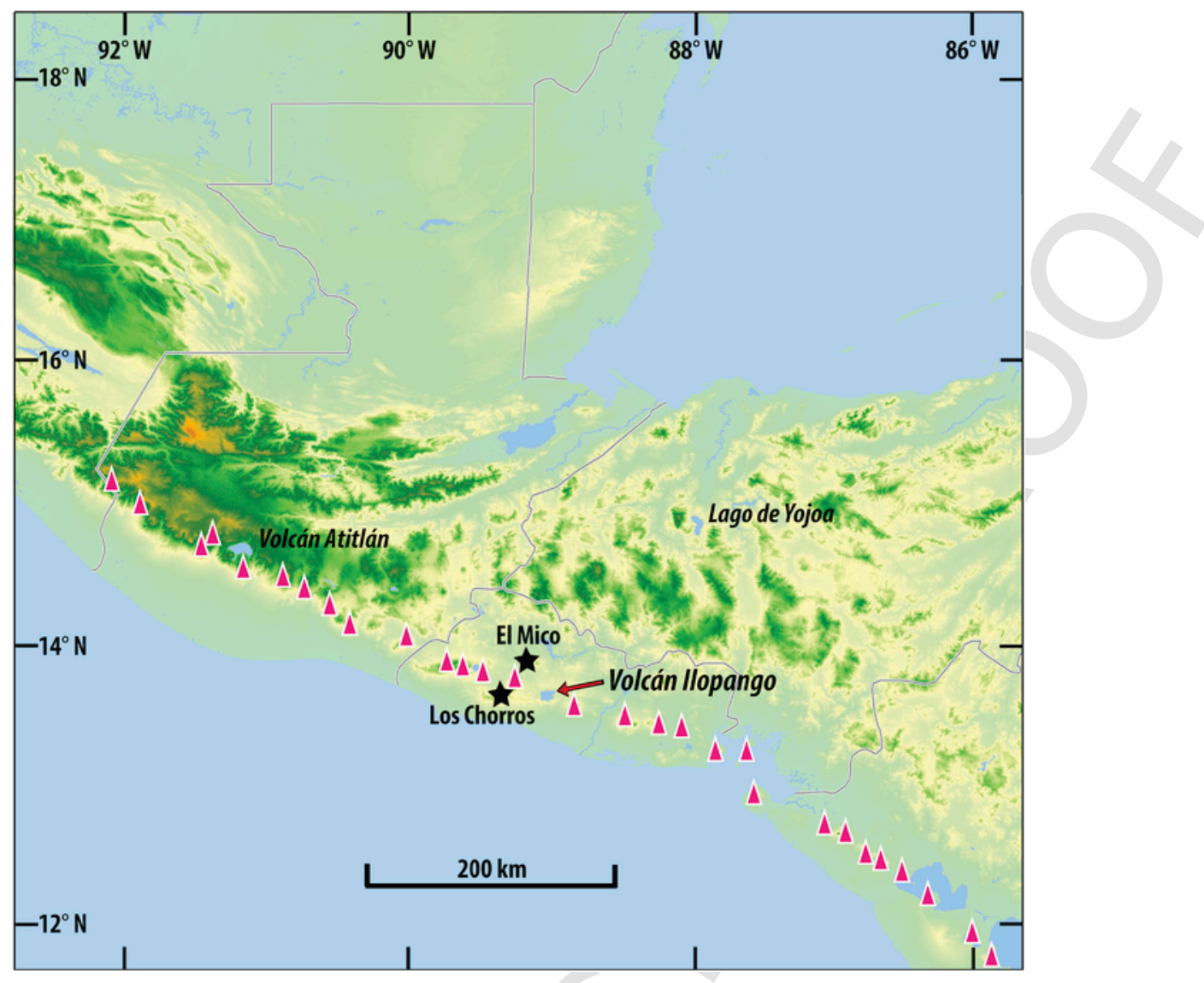

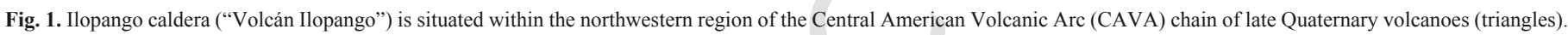

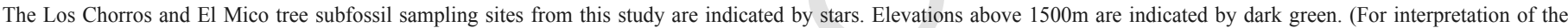
references to color in this figure legend, the reader is referred to the Web version of this article.)

fallen over in place or had been pushed over by machinery when the modern quarry was active (Fig. 2D). The in situ El Mico-A specimen was snapped off approximately $2.5 \mathrm{~m}$ above the TBJ contact leaving a jagged edge before it was completely covered - and preserved - by fallout tephra (Fig. 2B). El Mico-B had previously been cut with a chainsaw, probably around the time that the quarry had exposed it.

In order to test the hypothesis that El Mico-A was rooted in the pre-TBJ eruption paleosol, an excavation was carried out in July 2012 to expose the roots and paleo-surface contact. A $170 \mathrm{~cm}^{2}$ test pit was excavated and the hypothesis was confirmed. The excavation was suspended upon reaching the paleosol and exposing roots $<20 \mathrm{~cm}$ below the TBJ-paleosol contact, which was located $40-70 \mathrm{~cm}$ below the current surface (Fig. 2B). El Mico-A was felled with a chainsaw following the excavation. Complete cross-sections of both El Mico-A and El Mico-B were sampled in the field using a chainsaw (Fig. 2A and D). The field chainsaw cuts showed that El Mico-B was solid all the way through the trunk, but El Mico-A had a rotted core and another rotted section on one side of the trunk closer to the bark, a void that was filled with TBJ tephra (Fig. 2C).

The Los Chorros tree trunk segment was found $\sim 2 \mathrm{~km} \mathrm{NNW}$ of Santa Tecla, El Salvador, on the main road between San Salvador and Santa Ana embedded in a $\sim 6 \mathrm{~m}$ high section of TBJ ignimbrite. The Los Chorros trunk was evidently completely carbonized when erosively entrained into the pyroclastic density current. It was removed manually from the $6 \mathrm{~m}$-thick flow deposit along a highway road cut in 1998, where it was eroding out of the friable tephra deposit. A cross-section of the $36-\mathrm{cm}$ diameter carbonized stem was excavated the TBJ tephra with a trowel and wrapped in aluminum foil for transportation.

\subsection{Dendrology and dendrochronology}

The El Mico-A sample was identified by gross wood anatomy at the USDA/USFS Forest Products Laboratory as belonging to the genus Tabebuia, of which several species are found in El Salvador, including the very common species $T$. rosea, the national tree of El Salvador. Our sample had distinct-to-visible parenchyma bands that could be used to develop an approximate count of putatively annual growth rings. Distinct annual growth rings with marginal parenchyma have been identified in $T$. serratifolia growing in seasonal semi-deciduous forest plantations in Brazil with mean annual growth increments of $4.9 \mathrm{~mm}$ (Lisi et al., 2008). Annual rings and radial growth rates between 0 and $4.8 \mathrm{~mm} / \mathrm{yr}$ have been reported for $T$. chrysantha from southern Ecuador, but the possibility of missing or locally absent rings was raised due to indistinct or undetectable parenchyma (Volland-Voigt et al., 2011). Two other Tabebuia species (T. barbata and T. pentaphylla) have been reported to have visible-to-distinct growth bands characterized by density variations and parenchyma bands (Worbes, 2002). Subsamples were removed from the cross-section of El Mico A using a handsaw at intervals corresponding to 1 to 5 putative rings identified from wood anatomy including parenchyma bands. Uncertainty estimates in ring counts and therefore sample spacing were made using multiple identification criteria and repeated counts to develop a range of possible total rings along the sampling 

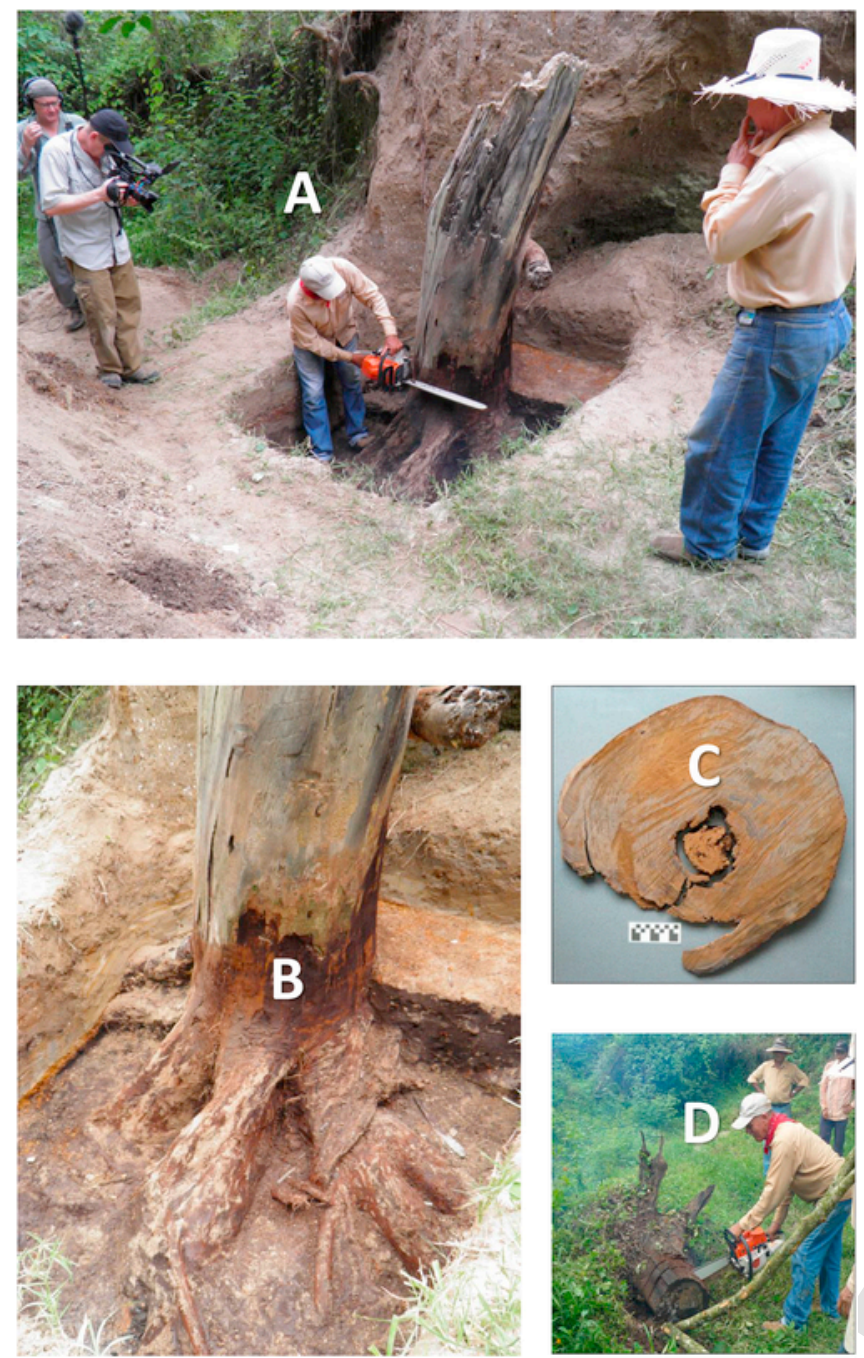

Fig. 2. El Mico site excavation and sampling. A) $76 \mathrm{~cm}$ diameter El Mico-A tree being sampled with a chainsaw. B) El Mico-A tree excavation pit showing rooted tree stump and TBJ tephra (light) overlying paleosol (dark). Excavation pit is $170 \mathrm{~cm} \times 170 \mathrm{~cm}$. C) cross section of El Mico-A showing rotted pith section. Scale $=10 \mathrm{~cm}$. D) $38 \mathrm{~cm}$ diameter El Mico-B being sampled with a chainsaw. Photos courtesy of P.A. and R.D

radius. Parenchyma and banding became more compressed at the outside of the tree and therefore larger uncertainties in ring counts were present near the bark than close to the pith and it is likely the outermost wood samples contain a significant number of individual years. Nevertheless, the existence of additional age constraints in El Mico-A allow it to provide the most precise dating information of the three trees.

El Mico-B was identified by gross wood anatomy at the USDA/ USFS Forest Products Laboratory as possibly belonging to the genus Caesalpinia. In contrast to El Mico-A, our El Mico-B sample had indistinct and inconsistent banding. Caesalpinia with distinct or distinct-with-difficulty growth bands and marginal parenchyma have been identified both in the Yucatan Peninsula (Roig et al., 2005) and in Brazil (Lisi et al., 2008). The lack of consistent banding prohibited using growth rings as a guide for sampling, so sub-sampling of the cross-section was achieved by depth at intervals of $0.5-1 \mathrm{~cm}$.

The Los Chorros sample was completely carbonized and its taxonomy could not be determined; subsampling was carried out at $2 \mathrm{~cm}$ intervals along the cross-section. The innermost ring (pith) was intact for both El Mico-B and Los Chorros, while the heartwood of El Mico-A was largely decomposed, leaving a $\sim 9 \mathrm{~cm}$ diameter cavity at the center of the tree trunk (Fig. 2C).

\subsection{Radiocarbon dating}

Milligram-sized samples of chemically pretreated wood and charcoal were combusted, graphitized, and measured by AMS at the Keck AMS lab, University of California Irvine. Results are quoted as conventional radiocarbon ages (Stuiver and Polach, 1977), with 1 sigma uncertainties that include contributions from scatter in repeated runs on samples and normalizing standards and from subtraction of backgrounds based on measurements of ${ }^{14} \mathrm{C}$-free wood and coal, as well as counting statistics.

The El Mico wood samples received a standard Acid-Base-Acid treatment $\left(30-\right.$ min treatments with $1 \mathrm{~N} \mathrm{HCl}$ and $1 \mathrm{~N} \mathrm{NaOH}$ at $75^{\circ} \mathrm{C}$, the base step repeated until the solutions remained clear) and were then bleached to holocellulose with a $1: 1$ mixture of $1 \mathrm{~N} \mathrm{HCl}$ and $1 \mathrm{M} \mathrm{Na}-$ $\mathrm{ClO}_{2}$ at $75^{\circ} \mathrm{C}$, washed repeatedly with ultrapure MQ water, and air dried. The Los Chorros samples were hard charcoal, showing well defined wood grain structures, but like similar samples from TBJ contexts dated previously (Dull et al., 2001), this apparently well-preserved material dissolved completely within $5-10 \mathrm{~min}$ in $1 \mathrm{~N} \mathrm{NaOH}$ at $60^{\circ} \mathrm{C}$. Thus, the full base step of the ABA pretreatment which was applied to the Los Chorros samples could not be used. Instead, two fractions from each sample were dated: an ABA-treated fraction (the material remaining after $\sim 5 \mathrm{~min}$ in base), and a base-soluble fraction reprecipitated with $6 \mathrm{~N} \mathrm{HCl}$ and washed repeatedly to near-neutral $\mathrm{pH}$. While we cannot completely exclude the possibility of contamination by younger humic acids that could not be removed by the abbreviated pretreatment, the location of the dated tree under several meters of absorptive volcanic ash and close correspondence of the radiocarbon ages for the two fractions, suggest that any such contamination is minimal.

\subsection{Bayesian analysis}

For each tree, we subsampled sequentially from the center (the pith) toward the outermost portion, taking between 8 and 18 individual samples along the growth radii. In order to take advantage of the ordered, sequential information provided by our radial tree sampling, we developed Bayesian chronological models using OxCal (Galimberti et al., 2004; Ramsey, 1995, 2009). At Los Chorros and for El Mico-B, where there was no additional guidance from wood anatomy, subsamples were simply taken at regularly spaced intervals, whereas for the samples from El Mico-A we used putative growth boundaries and anatomical structures as a guide to attempt to determine individual growth years and provide additional dating constraints. None of the individual trees could be precisely cross-dated to provide an annual resolution chronology, so each subsample reflects uncertainty in the number of years comprising each sample and the time between each sample increment. For El Mico-B and Los Chorros, the only additional depositional constraint was that the samples were in sequence with the inner wood samples (pith) being older than the outer (bark). For the larger diameter El Mico-A specimen, where we calculated both ring counts and estimates of uncertainty, we imposed these as additional depositional constraints in our model. Given the tropical location of central El Salvador, we included an additional parameter allowing for a mixture of northern and southern hemisphere ${ }^{14} \mathrm{C}$ calibration curves (INTCAL13 and SHCal13) for all three trees. 


\subsection{Calculation of eruption magnitude and volatile budget}

Total volume of TBJ tephra fallout is obtained by fitting straight lines to data on plots of $\ln$ [isopach thickness] versus square root [isopach area] following Pyle (Fierstein and Nathenson, 1992; Pyle, 1989) and integrating to infinity. Since the offshore thickness data are sparse, the shapes of the distal isopach contours are only estimates that introduce errors into the volume calculations depending on isopach construction. Nevertheless, it has been empirically shown that deviations in volume calculations imparted by individual choices of contours applied to the same data set are surprisingly low, between 5 and $8 \%$ (Klawonn et al., 2014).

Satellite images, and Google Earth have been used to outline the boundaries of the TBJ ignimbrite. Subsequently, these have been verified through ground-truthing, including observation of outcrops in the field and thickness measurements. The product of the area of each thickness isoline and the associated average thicknesses resulted in respective volumes that have been summed to yield the total minimum volume of the ignimbrite.

The erupted volatile masses for the TBJ eruption reported here are determined by combining our reassessed erupted magma volume and mass of this study with the degassed volatile fraction for the eruption determined by Metzner et al. (2014) using the petrological method (Devine et al., 1984). Chlorine, sulfur, and major elements were determined using a JEOL JXA 8200 electron microprobe (EMP) at GEOMAR in Kiel, Germany (Kutterolf et al., 2011) and a JEOL 8900 EMP at USGS in Menlo Park following standard lab methods (Sarna-Wojcicki et al., 1984). Natural and synthetic glasses and minerals were used as reference materials for calibration. Accuracy was monitored by reference material measurements on Lipari obsidian (major elements, e.g. (Hunt and Hill, 2001)), ALV (sulfur) and Ke13 (chlorine) glass (Tables S-1). Thirty individual point measurements were bracketed by two reference material measurements at the beginning and the end of each analytical series. Internal and external precision and accuracy of the monitor measurements were better than $2 \%$ for the major elements, $<5 \%$ for most minor elements including chlorine, and for sulfur. The latter has detection limits, in a best case, of $20 \mathrm{ppm}$, everything below in the matrix glass is considered to be degassed completely $(=\sim 0 \mathrm{ppm} \mathrm{S})$.

\section{Results}

\subsection{Age determination: $A M S^{14} C$ dates and bayesian analysis using} OxCal

Here we report one hundred new AMS ${ }^{14} \mathrm{C}$ dates: 46 from $\mathrm{El}$ Mico-A, 38 from El Mico-B, and 16 from Los Chorros (Fig. 3, Fig. 4, Tables S-2). All 100 AMS dates from this study cluster tightly around $\sim 1600{ }^{14} \mathrm{C}$ yr BP (Fig. 3), confirming the single sample results of the majority of the $14 \mathrm{C}$ determinations of the TBJ eruption age published over the past two decades (Dull et al., 2001; Kitamura, 2010; McNeil et al., 2010; Scott et al., 2006).

Fig. 4 shows the results of radiocarbon dating, calibration, and Bayesian sequential modeling. Each of the three panels shows the radiocarbon results for one of the tree samples analyzed here. Within the panels, each plot reflects the measurements made at a single depth, each consisting of 2-3 replicated radiocarbon measurements. The plots are ordered from the inside of the samples near the pith (top) toward the bark (bottom). The multiple individual radiocarbon measurements for each sample depth were first averaged and the

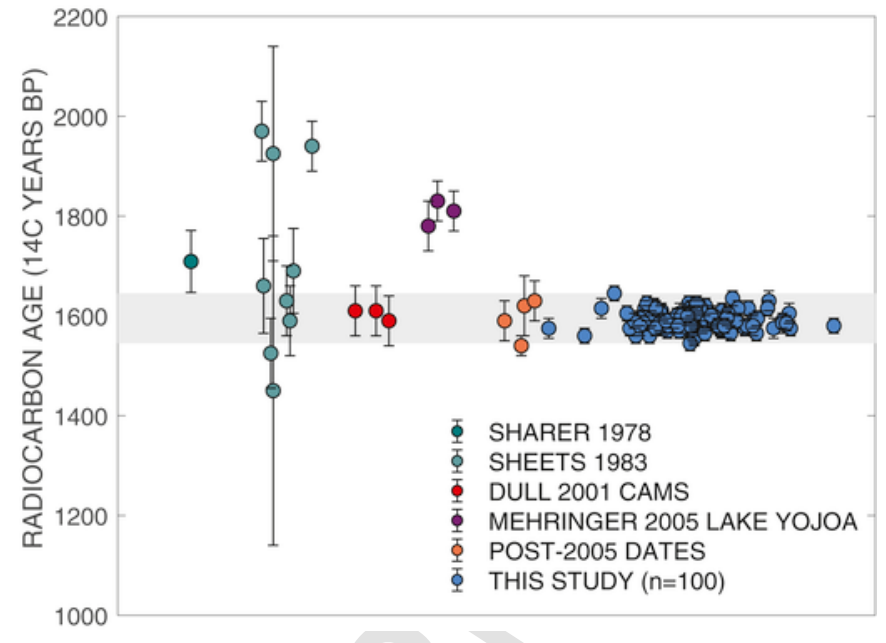

Fig. 3. All known reported TBJ 14C dates (uncalibrated) with error bars from 1978 (far left) through the present (far right). Dates are reported in Sharer (1978), Sheets (1983), Dull et al., (2001), Mehringer et al., (2005). "Post-2005" Dates include those from Scott et al., (2006), Kitamura (2010), McNeil et al., (2010). "This study" includes all 100 of the uncalibrated $14 \mathrm{C}$ dates reported in this study.

mean uncalibrated ${ }^{14} \mathrm{C}$ dates $\left({ }^{14} \mathrm{C}\right.$ years $\left.\mathrm{BP}\right)$ and uncertainties (years) are show along the left of each panel.

For El Mico-A, the median of the probability density for the outermost sample is $505 \mathrm{CE}$ with a 2-sigma calibrated range of 494-518 CE. For El Mico-B, where no additional depositional constraints beyond the sequences are imposed, the median modeled calibrated date for the outermost sample is $532 \mathrm{CE}$, with a full 2-sigma range of 438-549 CE but with the majority of the 1 sigma (526-544 CE, $53.8 \%$ ) and 2-sigma (507-549 CE, 65.7\%) posterior probability ranges in the first half of the 6th century. The Los Chorros sequence indicates an outer median modeled age of $521 \mathrm{CE}$ ( \pm 31 years) with a 1-sigma range of $471 \mathrm{CE}$ to $545 \mathrm{CE}$ and a 2-sigma range of 441-548 $\mathrm{CE}$, and once again a large fraction of the modeled 1-sigma posterior probability is in the first half of the 6th century (517-544 CE, $47.2 \%$ ). The median posterior probability for the mixing curves suggests a range of contributions from Southern Hemisphere radiocarbon sources of approximately $26 \%$ (El Mico-A) to $42 \%$ (El Mico-B and Los Chorros), although with large uncertainties in both cases.

Some caution is necessary when interpreting the posterior probability distributions from simple sequential depth modeling as applied to the El Mico-B and Los Chorros samples (Ramsey, 2009; Steier and Rom, 2000; Steier et al., 2001). Lowland tropical trees may also have asymmetrical growth and wedging, suppression, and local absence of growth rings, which adds additional uncertainty to the ring counts of El Mico-A (Anchukaitis and Evans, 2010; Brienen and Zuidema, 2005; Worbes, 1995). However, collectively the individual and sequential radiocarbon dates on the three trees all support a date in the range of 500-545 CE for the TBJ eruption (Figs. 4 and 5). The wiggle-matching and outermost dates on El Mico-A suggest an earlier date in that range, while the outermost samples of El Mico-B and Los Chorros support a later 530s-540s CE date.

The pre-eruption decomposition of the heartwood from El Mico-A is an important clue that might explain why the modeled death date of this tree is slightly earlier than the other two. Standing dead trees (snags) with decomposed cores are not uncommon in tropical dry forests (Vázquez and Renton, 2015), especially among Tabebuia species, and can persist rooted in situ for up to several decades. The earlier modeled death date for El Mico-A and the strong constraints imposed by the presence of countable rings together account for the 


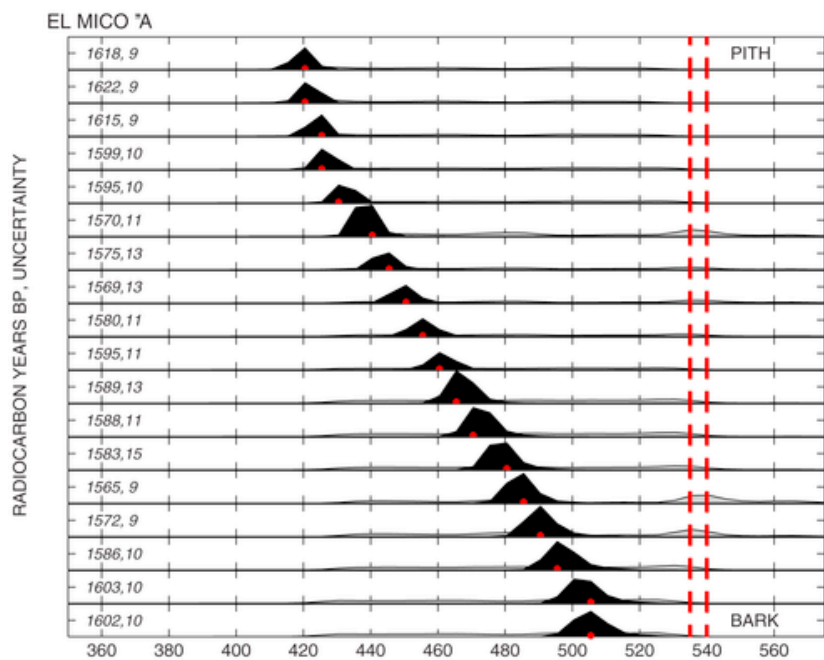

EL MICO 'B
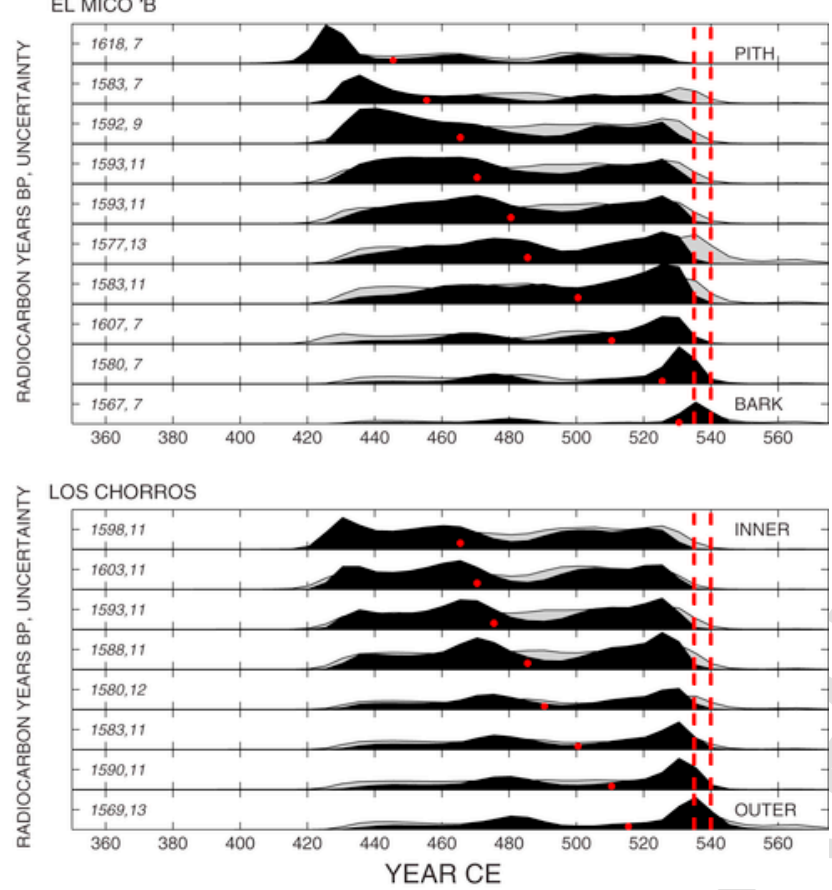

Fig. 4. Results of radiocarbon dating, calibration, and Bayesian sequential modeling from three subfossil tree trunks enveloped in TBJ tephra deposits. Gray shaded regions in each plot show the distribution of calibrated ages for the sample prior to Oxcal sequence modeling, while the black shaded region shows the posterior distribution once the order and spacing of the individual samples is included as additional information in the calibration. The red cross in each plot is the weighted median of the posterior distribution. Vertical red dashed lines indicate 536 and 540 CE. (For interpretation of the references to color in this figure legend, the reader is referred to the Web version of this article.)

very different character of the age distributions in Fig. 4 compared to those of the other two trees, and firmly place the outermost calendar date for El Mico-A as no earlier than ca. 500 CE. Using this as an additional constraint in Oxcal (Fig. 5), the eruption timing is then determined by the outermost dates on El Mico-B and Los Chorros to be between 503 and 545 at $95.4 \%$ probability.

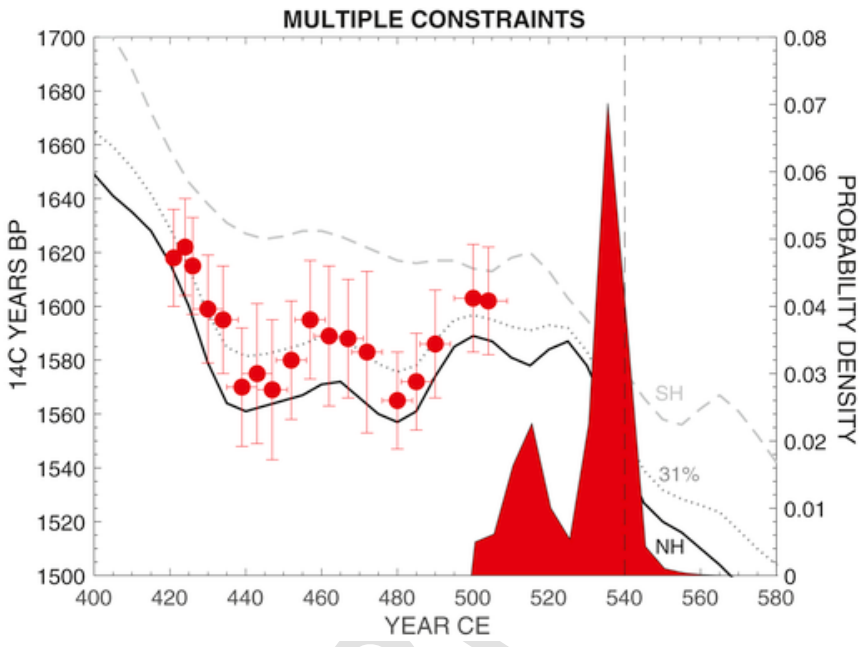

Fig. 5. Multiple constraints on the eruption date of Ilopango. Sequential wiggle-matched $14 \mathrm{C}$ dates with estimated ring counting and $14 \mathrm{C}$ measurement uncertainties (red symbols, $14 \mathrm{C}$ age scale on $\mathrm{LH}$ axis) place the outermost calendar date of El Mico-A no earlier than ca. $500 \mathrm{CE}$. When this is applied as an additional constraint (U[500,600]) in Oxcal, the combined outermost dates on El Mico B and Los Chorros then constrain $95.4 \%$ of the posterior probability for the eruption timing to lie between 503 and 545 CE (red filled area, scale on RH axis). $540 \mathrm{CE}$ is indicated with a vertical dashed line. Radiocarbon curves for the Northern Hemisphere (NH), Southern Hemisphere (SH), and $69 \% \mathrm{NH} / 31 \% \mathrm{SH}$ mix are also shown for comparison to the El Mico A samples (see text for details). (For interpretation of the references to color in this figure legend, the reader is referred to the Web version of this article.)

\subsection{Proximal tephra stratigraphy and the eruptive sequence}

The Ilopango TBJ eruption evolved through several eruptive phases that are reflected in a tephrostratigraphic succession that we divide into seven lithological units (I to VII; Fig. 6a). The overall phreatoplinian style of the eruption is attributable to rising rhyodacitic magma encountering surface water in a caldera basin that had already been formed by older eruptions. Pedrazzi et al. (2019) have recently studied the TBJ deposits and provide granulometric, petrographic and geochemical data; their stratigraphic subdivision into units $\mathrm{A}$ to $\mathrm{F}$ is largely similar to our division used below.

The internal architecture of unit I varies regionally around Ilopango. Commonly a $<1 \mathrm{~cm}$ thick brownish fine ash covers the underlying paleosol. To the west, this is successively covered by wavy beds of white fine ash, lithic-rich reversely graded fine lapilli and a moderately sorted ash bed with rounded pumice lapilli. To the south, the brown basal ash is overlain by a lensoid-bedded coarse-ash to fine-lapilli layer, and a white fine-ash layer with plant remains and leaf imprints (Fig. 6b). Juvenile particles range from pumiceous to almost dense, suggesting partial quenching by external water. We interpret that unit I formed by initial explosive blasts generating pyroclastic surges that defoliated the vegetation, as well as minor ash fallout to the west.

Unit II is a pumice lapilli fallout (Fig. 6b) that is stratified in its finer-grained lower third but massive and reversely graded in its upper part. The lithic content is low but includes a large fraction of hydrothermally altered fragments. Unit II records the development of a plinian eruption column that fluctuated initially but then became more stable and gained greater height until it terminated suddenly. The presence of hydrothermally altered lithics suggests some phreatomagmatic influence although the fallout is pumiceous. Our units I and II are in the stratigraphic position of units A0, A, and B of 


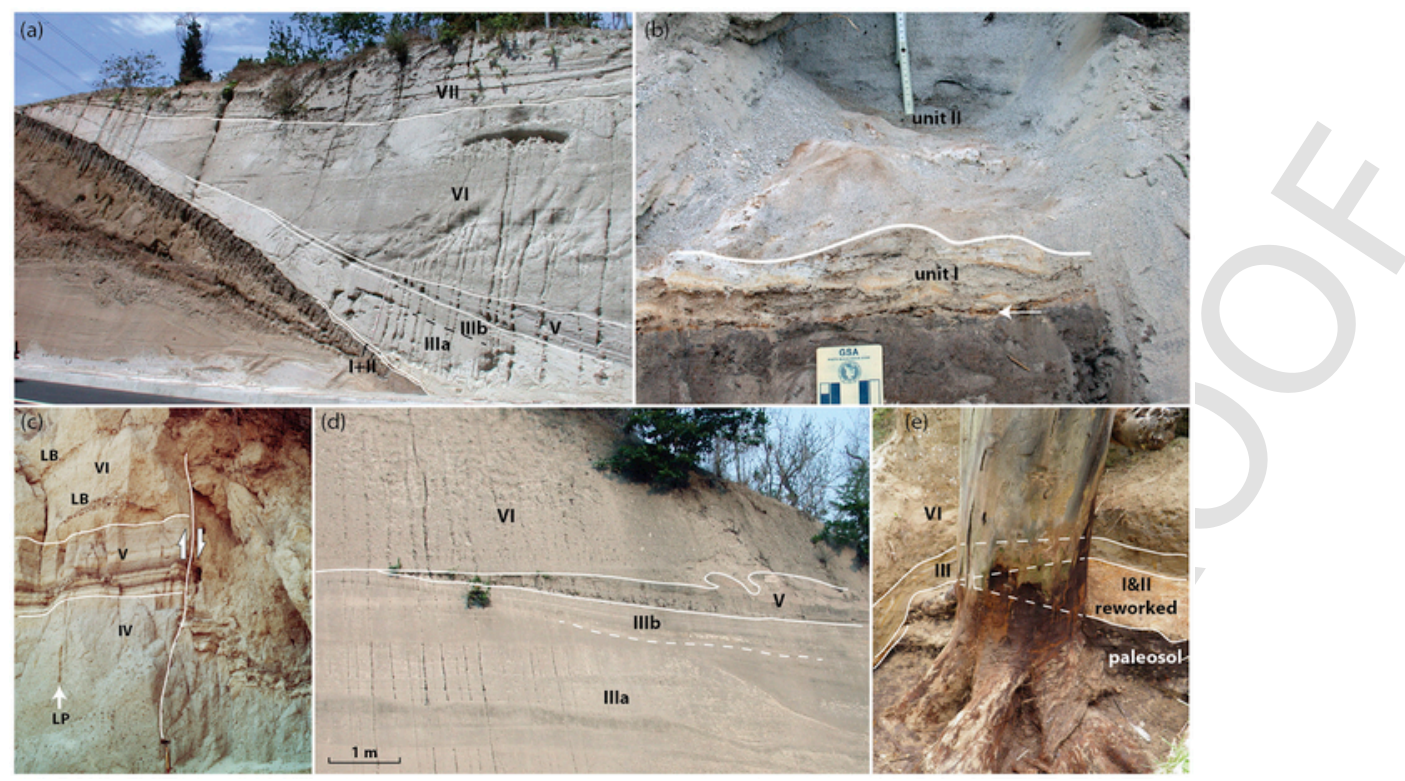

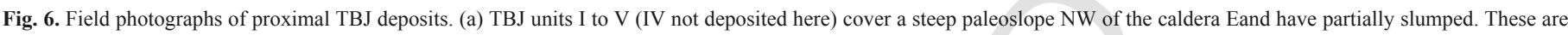

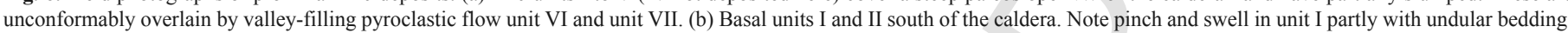

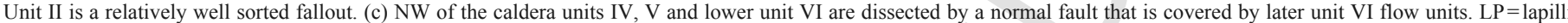

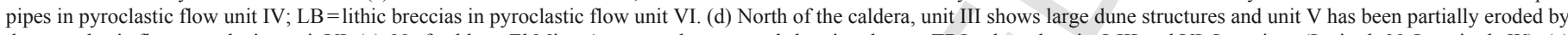

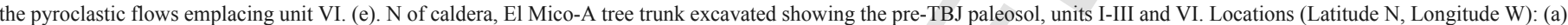
E009 13.76814, 89.15939 (b) E017 13.5861, 89.07371 (c) E011 13.7087, 89.12122 (d) E023 13.75637, 89.15869 (e) ELMC 13.89649, 89.16593.

Pedrazzi et al. (2019) but a detailed layer-by-layer correlation remains uncertain.

Unit III (equivalent to unit D of Pedrazzi et al., 2019) comprises a lower pyroclastic surge succession (IIIa) and an upper ash fallout succession (IIIb); the boundary between these subunits is not always clear and particularly obscure in the distal facies. Subunit IIIa has abundant antidune structures across the proximal range (Fig. 6d). In some proximal southwestern outcrops basal dune structures are lapilli-rich in channels but become finer-grained on overbanks. Most of subunit IIIa, however, consists of lapilli-poor ash with only poorly developed structures of density-segregation in the dunes, which are typically capped by fine-ash beds very rich in accretionary lapilli. The lithic fraction again contains abundant hydrothermally altered fragments. Subunit IIIb is a parallel-stratified sequence of internally massive to weakly stratified ash beds with very abundant accretionary lapilli. In many outcrops of the proximal to medial facies where it was emplaced on paleoslopes, unit III has viscously slumped downslope generating flow folds and other structures of soft-sediment deformation that had occurred immediately after emplacement and prior to coverage by the unit VI pyroclastic flows. Considering its wide dispersal, we interpret unit III as the product of a phreatoplinian eruption that entrained surface water and changed from emplacement of wet surge deposits to wet fallout deposits.

Unit IV is a pyroclastic flow unit with lapilli pipes only recorded in a valley NW of Ilopango (Fig. 6c). Elsewhere, unit III is immediately overlain by the lithic-rich stratified fallout succession of unit V (Fig. 6c), which equals unit $\mathrm{E}$ of Pedrazzi et al. (2019). A basal fine-lapilli fallout layer is capped by a normally graded ash layer that changes upward from planar to low-angle cross-bedding in its finer top section. The central, prominent part of unit $\mathrm{V}$ is a double pumice-lapilli fallout separated by a central ash layer. The lower fallout is reversely graded, the upper normally graded. Both are pumice-rich along the southerly fan axis but lithic-rich, finer grained and more poorly sorted in northerly directions. The top part of unit $\mathrm{V}$ is a succession of lithic-rich, mostly normally graded, massive to weakly stratified ash fallout beds often with accretionary lapilli enriched near their top. Where unit V has slumped on paleoslopes (Fig. 6d), the lower and central parts reacted mainly in a brittle fashion whereas the finer top part deformed plastically, indicative of wet emplacement. The abundance of lithic fragments suggests that magma-water interaction processes occurred deeper in the conduit during the phreatomagmatic eruption of unit V compared to unit III.

Unit VI (unit F of Pedrazzi et al., 2019) is an unwelded ignimbrite composed of at least five flow units that locally contain lapilli pipes and lithic breccias (Fig. 6c). The lower flow units are more lapilli-rich than the upper ones. The absence of intercalated co-ignimbrite ash deposits may be due to a rapid succession of the pyroclastic flows. There are four types of unconformities separating unit VI from the underlying TBJ units: (a) valley-filling flow units banking against earlier TBJ units that mantled the paleoslope (Fig. 6a), (b) smooth unconformities where the pyroclastic flows eroded into the underlying units (Fig. 6d), (c) angular, steep, irregular unconformities where underlying units had been eroded by water prior to ignimbrite emplacement, and (d) steps in the surface of the underlying units where these had been tectonically faulted close to the caldera rim prior to and during ignimbrite emplacement (Fig. 6c). These observations suggest that there was a break in eruptive activity between units V and VI, and that caldera subsidence began with the ignimbrite eruption.

Unit VII (unit G of Pedrazzi et al., 2019) begins with a massive white vitric ash layer which we interpret as the cumulative co-ignimbrite ash related to the underlying ignimbrite; this layer is not continuously preserved because the VI-VII boundary is often an erosive contact (Fig. 6a). Locally unit VII has a dune-bedded pyroclastic ash-surge deposit at its base. Generally, unit VII is a succession of (1) thin pyroclastic flow units often with accretionary-lapilli-bearing co-ignimbrite ash beds at top, (2) normally graded ash fallout layers with accretionary lapilli, and (3) massive fine-grained flow deposits probably formed by highly concentrated aqueous floods. Unit VII

repre- 
sents the terminal phase when relatively weak eruptions continued while erosion and reworking of the tephra proceeded.

\subsection{Tephra chemical composition and correlation of distal deposits}

The TBJ magma had a rhyodacitic composition and was phenocryst-poor (pl, am, opx, mt, ap). A minor compositional zonation of the magma is revealed by linear increase of $\mathrm{K}_{2} \mathrm{O}, \mathrm{Ba}, \mathrm{Zr}$ but decrease of $\mathrm{TiO}_{2}, \mathrm{Al}_{2} \mathrm{O}_{3}, \mathrm{FeO}, \mathrm{MgO}, \mathrm{CaO}, \mathrm{P}_{2} \mathrm{O}_{5}$ from 70 to $73 \mathrm{wt} \% \mathrm{SiO}_{2}$. Such trends are extended down to about $50 \mathrm{wt} \% \mathrm{SiO}_{2}$ by matrix compositions in mingled pumices found in unit VI (F; Pedrazzi et al., 2019). The occurrence of rare very crystal-rich gray pumice of silicic-andesitic bulk composition in the upper flow units of the TBJ ignimbrite (unit VI) indicates that magma withdrawal had reached the top of a basal cumulate layer underneath the main rhyodacite magma.

We have analyzed matrix glasses of rhyodacitic pumice samples from all seven units to constrain the compositional correlation field for TBJ in Fig. 7. However, we do not include the glass compositions of the rare mingled pumices because these do not occur in distal deposits. TBJ glass compositions are clearly distinct from those of other major tephras (e.g. from Coatepeque caldera) in El Salvador and thus are well suited for geochemical fingerprinting. There is, however, compositional overlap between TBJ and the older Ilopango tephras TB2, TB3, and TB4. TB2 and TB3 are only distributed immediately around Ilopango caldera. TB4 is a pumice fallout deposit that can be distinguished from TBJ particularly in archaeological and marine sites by its much greater age $(36 \mathrm{ka})$. Hence the compositions of distal terrestrial and marine tephras (compiled in supplement Tables S-3) can clearly be attributed to TBJ (Fig. 7). Only the Lago Amatitlán sample is a slight outlier, but the TBJ tephra has been geochemically identified independently in lake sediments there by Lohse et al. (2018).

The first positive identification of the TBJ tephra by geochemical fingerprinting outside of El Salvador was reported from sediment cores extracted from Lago Yojoa in Honduras (Mehringer et al., 2005). Since that time similar geochemical fingerprinting has helped identify distal TBJ tephra deposits from Lago Amatitlan, Guatemala (Lohse et al., 2018), the Copán Valley in Honduras (McNeil et al., 2010), and on the flanks of the San Miguel volcano in Eastern El Salvador near the Gulf of Fonseca (this study). Measurements carried out at several locations on and around the San Miguel volcano show that 20-30-cm-thick TBJ tephra deposits are preserved there (Scott et al., 2006), an eroded remnant of what was originally likely a significantly thicker regional deposit as attested to by tephra erosion studies carried out following the $1980 \mathrm{Mt}$. St. Helens eruption (Collins and Dunne, 1986; Gran et al., 2011). Up to $150 \mathrm{~cm}$ thick TBJ tephra deposits have been observed elsewhere in eastern El Salvador (Rapprich et al., 2010), a region which was previously thought to have had little or no tephra attributable to the TBJ eruption (Andrews, 1976). In addition to these terrestrial deposits, marine sediment cores on the $\mathrm{Pa}$ cific margin from Guatemala to Nicaragua contain ash beds within a few decimeters below seafloor that are geochemically fingerprinted as TBJ deposits (Kutterolf et al., 2008) (Fig. 7).

\subsection{Eruption magnitude and volatile budget}

An initial TBJ magnitude estimate based on tephra deposits in central and western El Salvador suggested a total bulk volume of $\sim 18$ $\mathrm{km}^{3}$ Dense Rock equivalent (DRE) (Hart and Steen-McIntyre, 1983), equivalent to a VEI of 6 . The correlated distal terrestrial and marine TBJ deposits permit a reassessment of the emitted magma volume.
Applying the method of exponential thickness decay over the distribution area (Fig. 9) after Fierstein and Nathenson (1992) (Fierstein and Nathenson, 1992) to the TBJ fallout deposits yields a revised tephra volume of $87.4 \mathrm{~km}^{3}$. The TBJ ignimbrite has an approximately radial distribution up to $45 \mathrm{~km}$ from Ilopango caldera, covering most of the terrain but with greater ponded thicknesses in the valleys (Fig. 8). We estimate a bulk ignimbrite volume of $\sim 19.1 \mathrm{~km}^{3}$, which includes a conservatively estimated intra-caldera volume of $5 \mathrm{~km}^{3}$ based on the ignimbrite thickness exposed at the caldera rim. Combined, these data yield a minimum total TBJ tephra volume of $106.5 \mathrm{~km}^{3}$, corresponding to an erupted magma mass of $9.16 \times 10^{13} \mathrm{~kg}$, a magma volume of $43.6 \mathrm{~km}^{3}$ DRE, and a calculated magnitude (Mason et al., 2004; Pyle, 1995) of 7.0 (VEI 7). Pedrazzi et al. (2019) obtain a total DRE volume of $30 \mathrm{~km}^{3}(\mathrm{M}=6.8)$ as the sum of volumes determined for each unit; they attribute all distal data to unit G (our unit VII) and none to the lower units. Nonetheless our studies agree in order of magnitude and reaffirm the TBJ eruption as one of ten largest eruptions on Earth over the past 7000 years (Lavigne et al., 2013).

The TBJ DRE volume is significantly less than the estimated subsidence volume of $111 \mathrm{~km}^{3}$ of the $13 \mathrm{~km}$ by $16 \mathrm{~km}\left(185 \mathrm{~km}^{2}\right)$ and 600-m-deep ( $\sim 400 \mathrm{~m}$ average rim elevation plus $\sim 200 \mathrm{~m}$ average lake depth) Ilopango caldera. This is not surprising because Ilopango had experienced a number of previous large-volume caldera-forming eruptions. Complementing the TBJ volume by the cumulative volume of Pleistocene (last 100 kyrs) tephra deposits underlying TBJ in and around the caldera yields a total of $\sim 65 \mathrm{~km}^{3}$ DRE which gets closer to balancing the caldera subsidence volume (Kutterolf et al., 2008; Schindlbeck et al., 2018).

Sulfur concentrations are $\leq 100 \mathrm{ppm}$ in rhyolitic TBJ melt-inclusions ( $\sim 78 \mathrm{wt} \% \mathrm{SiO} 2 ; 40-96 \mathrm{ppm} \mathrm{S}$ in melt inclusions of plagioclase, pyroxene, amphibole, spinel), and $<20 \mathrm{ppm} \mathrm{S}$ (where $20 \mathrm{ppm}$ is the detection limit) in matrix glasses. Without considering emission of a pre-eruptive sulfur-rich fluid phase, evident from abundant fluid inclusions in the phenocrysts, and assuming a complete degassing during eruption (i.e., of $\sim 96 \mathrm{ppmS}$ ), we estimate a minimum yield of $\sim 9 \mathrm{Tg}$ of S using our reassessed eruption magnitude. However, considering the volatile/K2O ratios (Freundt et al., 2014), we expect that the parental basaltic magma of the evolved TBJ magma had a sulfur content of at least 1000-2200 ppm, which is typical for Central America (Sadofsky et al., 2008). The magma would have exsolved a sulfur-rich fluid phase during magmatic differentiation (Wallace and Gerlach, 1994), which is supported by existing fluid inclusions in phenocrysts (Kutterolf et al., 2015). If all of this sulfur were released in gaseous form during the TBJ eruption, then an upper bound on the $\mathrm{S}$ yield would be 90 to as much as $200 \mathrm{Tg}$, an order of magnitude greater than the estimates from the petrological method, an excess comparable to that determined for other eruptions like that of Pinatubo in 1991 (Yang and Schlesinger, 2002). Thus, while the TBJ sulfur emissions can only be weakly constrained given uncertainties in the partitioning and fate of $\mathrm{S}$ in the magma, a $\mathrm{S}$ yield to the atmosphere exceeding that of Tambora: 28 Tg S (Self et al., 2004) by 10-40\% - as implied from ice-core data (Larsen et al., 2008; Sigl et al., 2015) - is reasonable.

\section{Discussion}

\subsection{The age of the TBJ eruption and global significance}

Our new age constraints on the timing (between 500 and $545 \mathrm{CE}$ and more likely in the latter decade of this interval), magnitude (7.0 or around $44 \mathrm{~km}^{3}$ DRE volume) and sulfur yield (9-200 Tg S) of the TBJ eruption, and the tropical location of the volcano, strongly sug- 

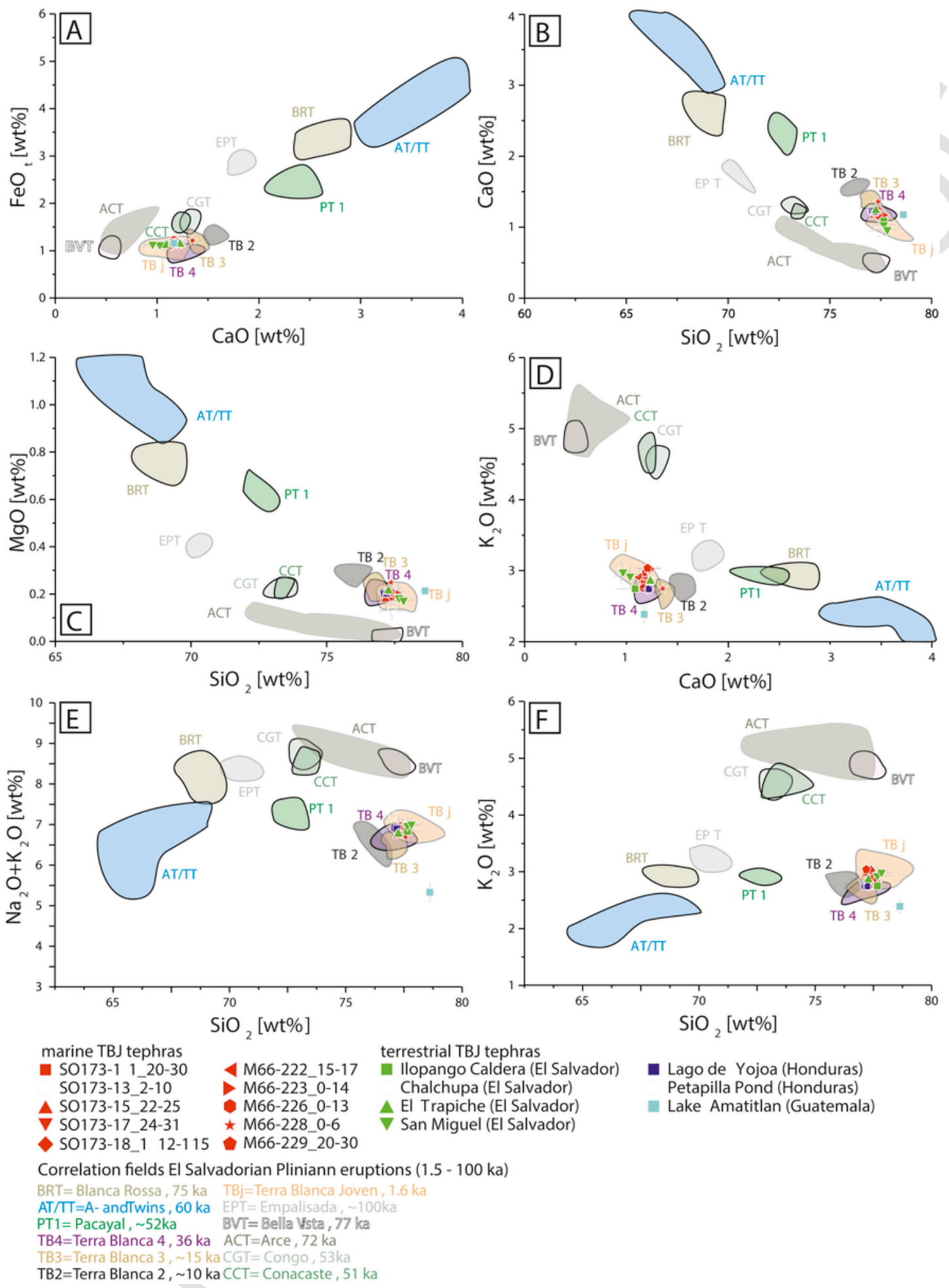

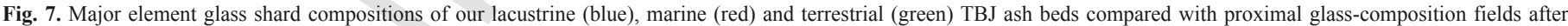

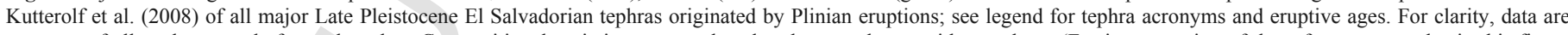

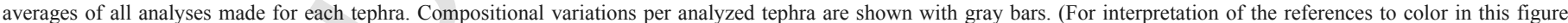
legend, the reader is referred to the Web version of this article.)

gest it should be represented in the ice core records of both Antarctica and the Arctic. Further, the stratospheric sulfate aerosol generated can be expected to have perturbed the climate of the Northern Hemisphere. Considering the most recently published bipolar sulfate records of global volcanism, there is only one prominent tropical event recorded in both Greenland and Antarctica in the relevant time interval, and that is the 540 CE signature (Gautier et al., 2019; Sigl et al., 2015). Further evidence attesting to the tropical volcanic source 


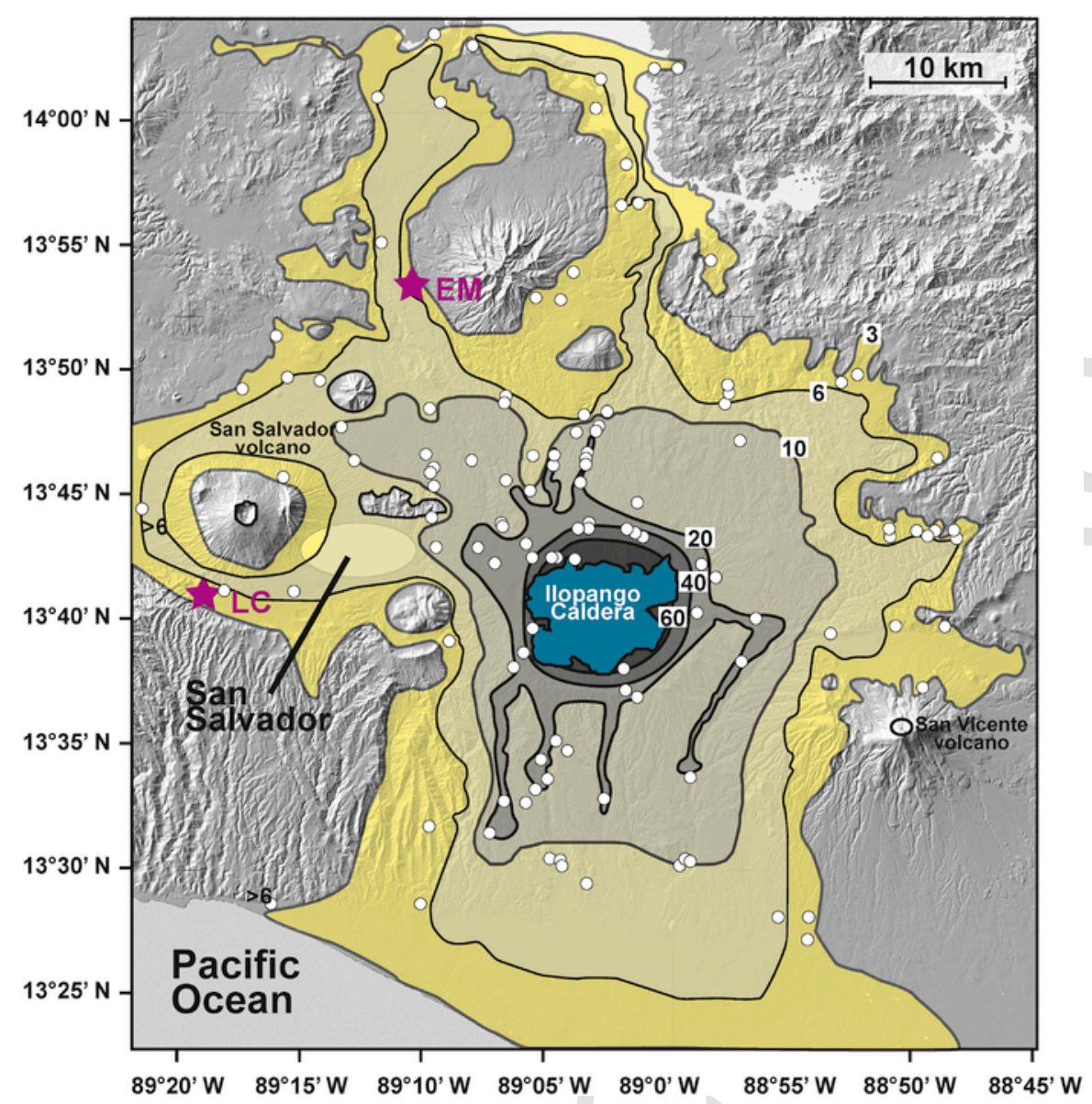

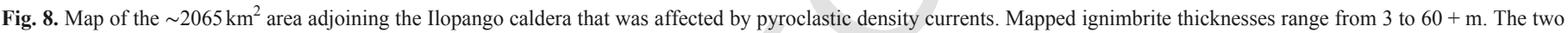

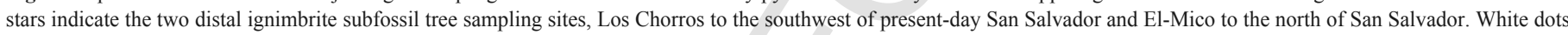
denote field measurements of ignimbrite thickness. Units of thickness are in meters.

of the $540 \mathrm{CE}$ bipolar ice core signatures has been found in isotopic composition of the sulfur extracted from the corresponding layer in Antarctic ice (Gautier et al., 2019). As the only signal commensurate with the timing and scale of the TBJ eruption in this timeframe, we argue that there is compelling evidence to associate the eruption with the $540 \mathrm{CE}$ ice core anomaly. The only definitive way to further strengthen the connection between Ilopango and the $540 \mathrm{CE}$ ice core anomaly would be to geochemically fingerprint volcanic glass shards extracted from the coeval ice core levels, and as yet none have been found (Sigl et al., 2015).

Applying present-day average wind conditions to the time of the TBJ eruption, the southeastward dispersal of distal TBJ ash at upper troposphere-lower stratosphere levels would most likely have occurred during the wet season between June and November. Northwesterly winds are rare in this part of Central America where NE tradewinds are typically dominant, but are most common from September to November, when the North Atlantic Subtropical High (NASH) is weakened and displaced to the East (Sáenz and Durán-Quesada, 2015). This tephra deposition pattern lends credence to the theory that the TBJ eruption most likely occurred in autumn of $539 \mathrm{CE}$, although this assessment on the precise timing is only deductive speculation at this time.

Much has been written about the climatic downturn of the mid-6th century CE, and its associations with volcanism and demographic consequences (e.g., the outbreak of bubonic plague in Europe, Western Asia and the Nile Delta region circa 541-544 CE). Cogent and critical reviews of the few direct and the numerous proxy sources of evidence can be found in Newfield (2018) and Moreland (2018), and here we only make brief further remarks to foreground the global significance of identifying the TBJ eruption as source of the $540 \mathrm{CE}$ bipolar ice core anomaly and thereby linking it to a major climatic downturn that affected parts of Eurasia (e.g., Büntgen et al., 2016). Stothers (1984b) did much to draw attention to the Byzantine and other sources pertaining to the 'mystery cloud' of $536 \mathrm{CE}$, and numerous studies went on to consider volcanological implications and the evidence for the associated fallout in the polar ice core records. In part, by resolving a chronological issue in Greenland ice core chronology, Sigl et al. (2015) discriminated two major eruptions in the ice cores, one presumed to be associated with the $536 \mathrm{CE}$ 'mystery cloud', the other occurring some four years later. Through application of a coupled aerosol-climate model, Toohey et al. (2016) show how the two significant, sulfur-rich eruptions occurring within a matter of years of each other were capable of decadal-scale forcing of Northern Hemisphere climate including perturbations of Arctic sea ice extent and persistence. In other words, without the TBJ eruption, the intensity and duration of the climatic downturn documented in Eurasian tree ring records would have been reduced. In terms of understanding societal impacts, this is significant because while contemporary coping strategies could likely absorb the impacts of an individual year of poor harvests, successive years of dearth would have taken an immense human toll (Newfield, 2018). The relevance of the climatic downturn in understanding the arrival of plague in the Nile 


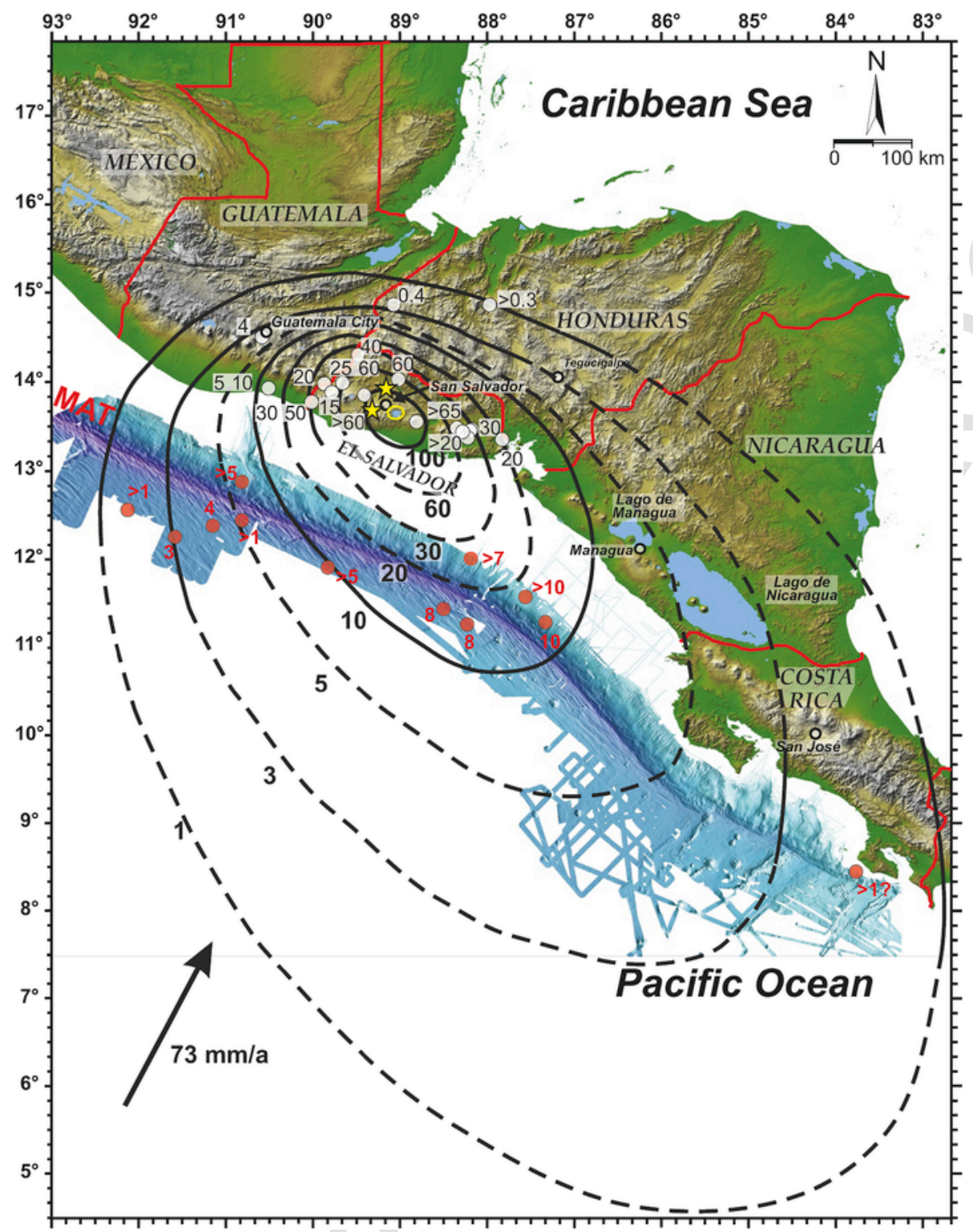

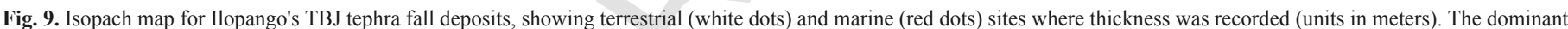

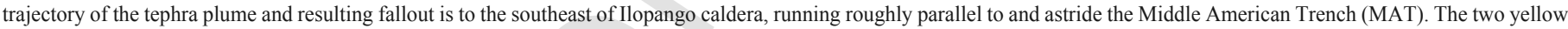
stars are the subfossil tree sampling sites. (For interpretation of the references to color in this figure legend, the reader is referred to the Web version of this article.)

Delta region in 541 CE remains unclear and debated (Harper, 2017; Keys, 2000; Newfield, 2018), but climatically-triggered famine and malnutrition would likely have exacerbated plague mortality in any case - as well as its spread - by leading to longer lines of trade (Newfield, 2018).

\subsection{Impacts of the TBJ eruption in the mayan realm}

Along with the global climate and societal effects discussed above, the TBJ eruption dealt a devastating blow to Maya populations in and around present-day El Salvador (Dull, 2004, 2007; Dull et al., 2001; Sheets, 1979, 2012). Two earlier studies included reviews of the archaeological (Dull et al., 2001) and paleoecological (Dull, 2004) evidence for depopulation following the TBJ eruption. A map was generated that outlined the area of demographic collapse following the event (Dull et al., 2001), which included sites throughout central and western El Salvador (e.g. Cara Sucia, Chalchuapa,
Valle Zapotitán, San Salvador, Rio Lempa) together with southeasternmost Guatemala (e.g. Santa Rosa, Escuintla, Jutiapa). Here we refine and expand that map (Fig. 10), while also more precisely delineating areas where we expect there would have been no survivors due to inundation by pyroclastic density currents (Fig. 8). Several large archaeological sites were apparently abandoned for at least several decades in the $\sim 20,000 \mathrm{~km}^{2}$ area of deep $(>35 \mathrm{~cm})$ initial tephra deposits, including Chalchuapa, Cara Sucia, and San Andrés in central and western El Salvador (Fig. 10). The 6th century date of the TBJ reported in this study allows us to reconsider the period of abandonment, which we now know was about a century shorter than was presumed in the earlier 2001 study; indeed, most of these regions were resettled - some with monumental architecture completed - by the middle of the 7 th century.

A substantial change from the 2001 map of the area of demographic collapse is the inclusion of virtually all of eastern El Salvador, following the recent identification of remnant deposits of 


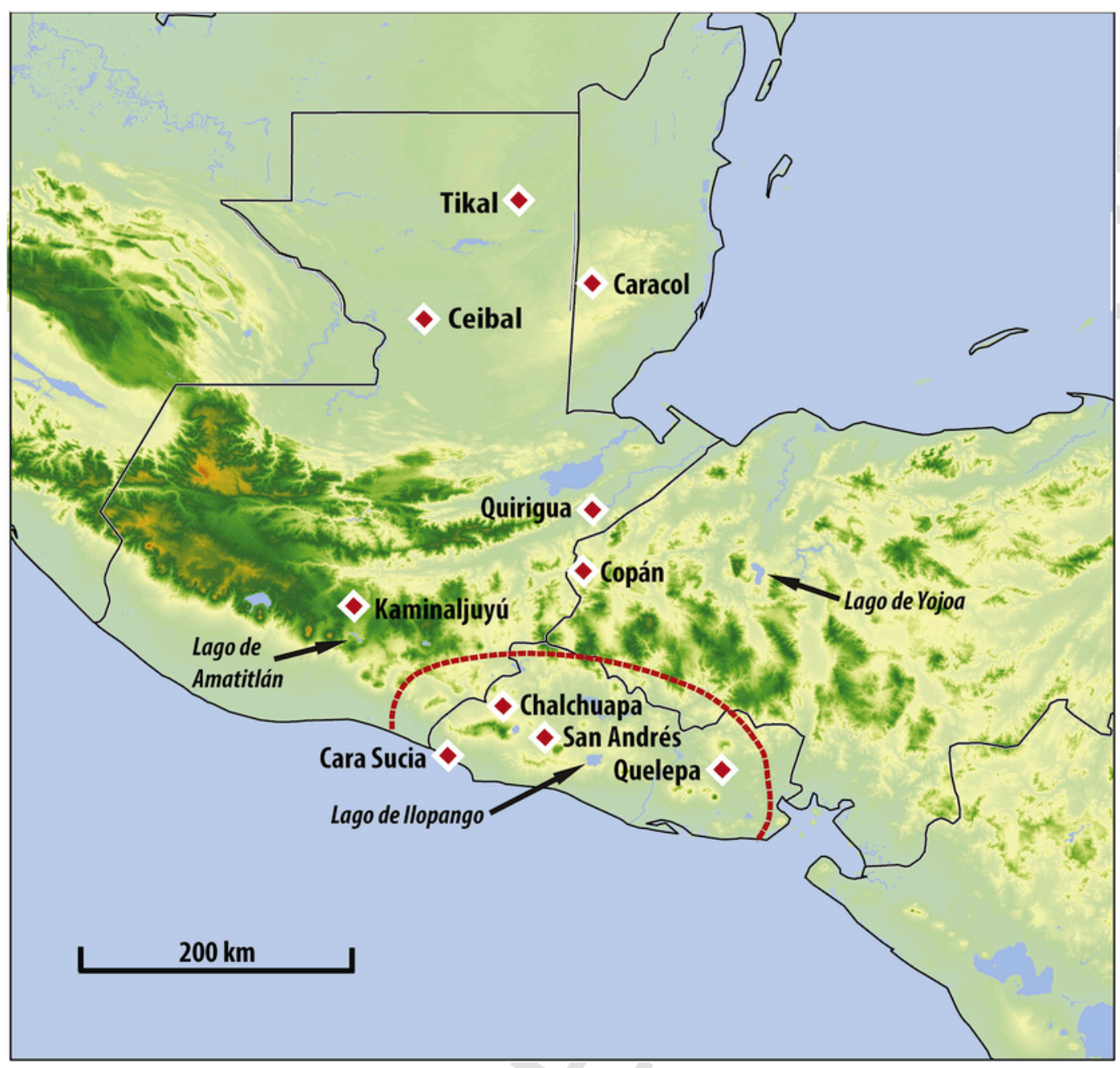

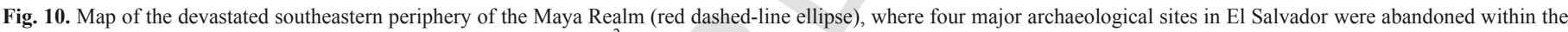

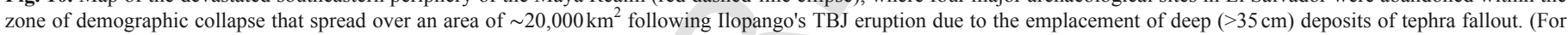
interpretation of the references to color in this figure legend, the reader is referred to the Web version of this article.)

$20 \mathrm{~cm}$ to in excess of $100 \mathrm{~cm}$ thickness of TBJ tephra throughout the region (Rapprich et al., 2010; Scott et al., 2006) (Fig. 11). A detailed 1976 report on excavations at Quelepa (Andrews, 1976), arguably the most important and best-studied ancient urban center in eastern El Salvador, concluded (p.182) that "the volcanism they document in the west apparently did not affect Quelepa to any great extent." However, Andrews was operating under the assumption that the TBJ eruption occurred in the 1st or 2nd century of the Common Era, not the 6th. Indeed, an abrupt and radical departure from historical patterns did occur in Quelepa around the 6th century CE (Ashmore, 2014), marking the abrupt shift from the Shila to the Lepa cultural phases (Andrews, 1976). The cultural affinities at Quelepa up until the 6th century CE were strongly tied to western El Salvador, the Guatemalan highlands, and Copán (Honduras), but these connections were abruptly terminated by the close of the 6th century, when the Shila phase ceremonial focus at the site was abandoned (Andrews, 1976; Ashmore, 2014). The 6th Century disruption marks the only dramatic discontinuity and cultural realignment of the entire 1500 year occupation (circa $500 \mathrm{BCE}$ - $1000 \mathrm{CE}$ ); this, together with relatively thick eroded remnant TBJ deposits preserved just $\sim 15 \mathrm{~km}$ to the south on the slopes of the San Miguel volcano (Fig. 11A and B), suggests that the TBJ eruption was responsible for the abrupt isola- tion of Quelepa and likely its temporary abandonment. Lepa phase construction after the abandonment commenced at circa $625 \mathrm{CE}$ (Andrews, 1976), which is consistent with 7th century CE resettlement in Chalchuapa and the Zapotitán Valley (Dull et al., 2001).

\subsubsection{Estimating sixth century population densities and TBJ fatalities}

When Europeans first arrived there in the early 16th century, El Salvador was the most densely populated country in Latin America, and remains so today (Fowler, 1988; Sheets, 1979). Fowler estimates the Post-classic indigenous population of El Salvador to have been $\sim 600,000-700,000$ in $1524 \mathrm{CE}$, or an average density of 28.5-33.0 people $/ \mathrm{km}^{2}$. Although archaeological data are insufficient to precisely estimate early 6th century population densities across all of El Salvador, we consider an earlier published estimate of population density of $40 / \mathrm{km}^{2}$ (Sheets, 1979) across central and western El Salvador at the time of the TBJ eruption to be reasonable. Regional estimates have also been made for smaller geographic areas in central El Salvador, such as the greater Zapotitán Valley region, where prehistoric populations peaked in the Late Classic Period following post-TBJ recolonization at $70-180 / \mathrm{km}^{2}$ and then declined to $50-120 / \mathrm{km}^{2}$ by the contact period (Black, 1983). Similarly, prehistoric Maya populations peaked throughout most of the Maya lowlands (Johnston, 

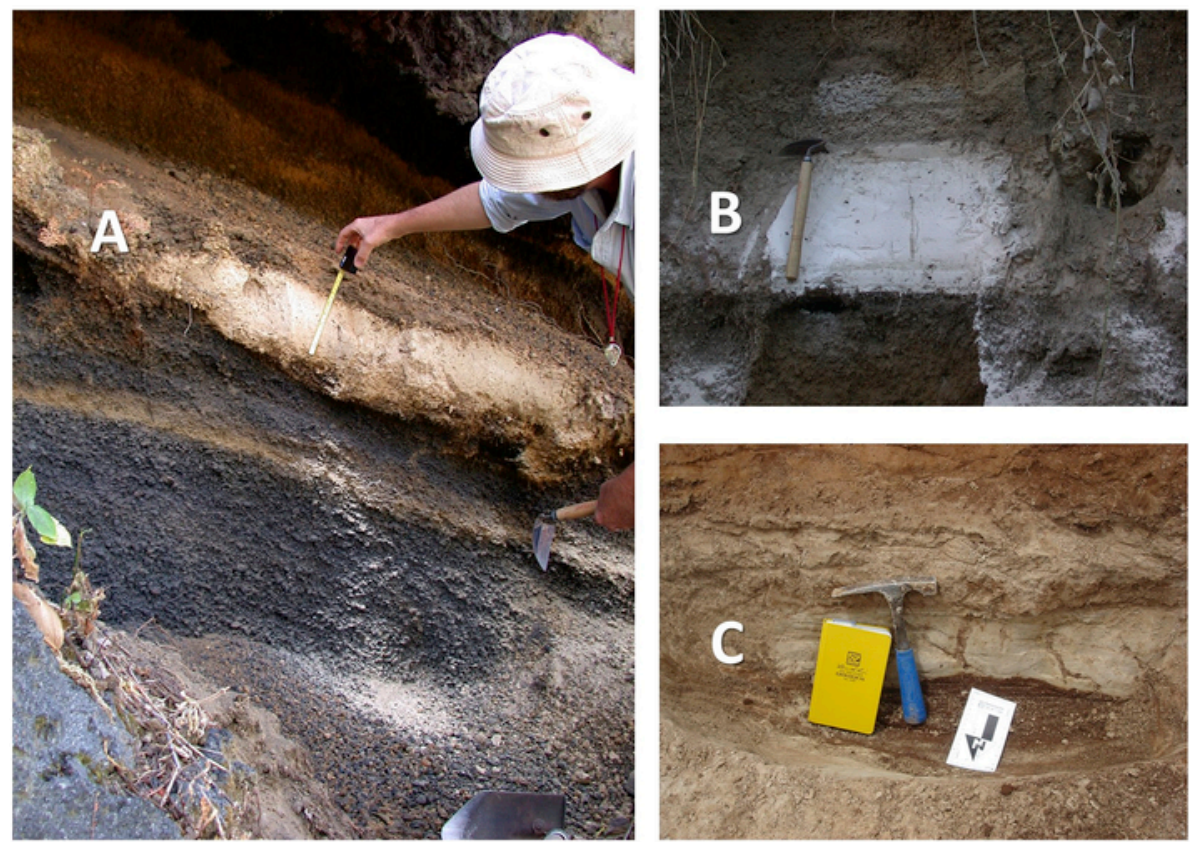

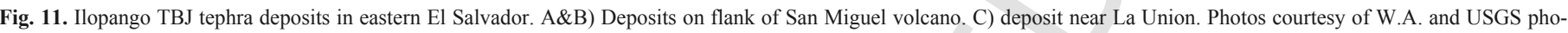
tographs courtesy of C.A. Gardner and W.E. Scott.

2003) and southern highlands (Fowler, 1988) during the Classic period and decreased thereafter, suggesting that the eruption occurred during a time of near maximum prehistoric population density.

Dozens of buried agricultural fields dating to the TBJ eruption have now been discovered and studied throughout central, western, and northern El Salvador (Amaroli and Dull, 1999; Dull, 2006; Fowler and Earnest, 1985; Sheets, 1982; Zier, 1980, 1983) and new road cuts routinely expose more (Fig. 12). These ridge and furrow milpa systems are indicative of high yield food production systems practiced by sedentary farmers. Much more labor intensive than simple slash-and-burn swidden systems, these 'high performance' milpas have been found at numerous sites under the TBJ tephra, and maize fields of nearly identical morphology have been found in the basin of San Salvador as far back as 830 BCE (Amaroli and Dull, 1999; Dull, 2006) (Fig. 12B), suggesting very early agricultural intensification in the region, which was presumably tied to population pressure. These fields and the preserved pre-TBJ humanized landscape that they represent could be used in future studies as a basis for more precise population estimates at the time of the eruption. Terrestrial primary production, including agricultural production, plummeted in the post-eruption Salvadoran landscape, much of it covered in meters of ash, which would have been the primary limiting factor on the persistence of human settlement in the region.

We choose conservative population density numbers for the time of the TBJ eruption: $20-40 / \mathrm{km}^{2}$ averaged over the intensively-cultivated lowland valleys and intervening highlands of Central El Salvador that were inundated by pyroclastic density currents (Figs. 8), and $5-20 / \mathrm{km}^{2}$ for the region of depopulation attributable to thick tephra fallout spreading from southeastern Guatemala to eastern El Salvador (Fig. 9). The latter number includes some areas in the northern mountains of El Salvador that were certainly less densely populated than the volcanic highlands and the adjacent Pacific lowlands.

Based on the population density estimate of 20-40 people $/ \mathrm{km}^{2}$ for the intensively-cultivated agricultural lands (Figs. 8 and 12) adjoining the Ilopango caldera, and assuming no mass evacuation ahead of the paroxysmal eruptions, we estimate up to $40,000-80,000$ fatalities in the $\sim 2000 \mathrm{~km}^{2}$ area inundated by pyroclastic density current deposits at least $3 \mathrm{~m}$ thick (Fig. 8). Additionally, if we assume that at least another $\sim 20,000 \mathrm{~km}^{2}$ of the southeastern Maya periphery was left uninhabitable by heavy tephra fall of $35 \mathrm{~cm}$ or more (Fig. 10), with a modest population density over that area of 5-20 people $/ \mathrm{km}^{2}$, then some 100,000-400,000 survivors may have attempted to flee the region. A significant fraction of the eruption survivors and refugees may well have perished due to post-eruption disease compounded by lack of food and clean water, as documented after Tambora in 1815 and Santa Maria, Guatemala in 1902 (Oppenheimer, 2003; Tanguy et al., 1998). Indeed, more than two-thirds of all fatalities attributed to volcanic eruptions globally since 1500 have occurred not during the eruptive phases, but in the days, months, and even years following eruptions (Simkin et al., 2001). In the case of Tambora's 1815 eruption, the ratio of post-eruption to syn-eruption fatalities is of order five-to-one (Oppenheimer, 2011). Considering that Sumbawa island (on which Tambora is located) likely had a less-intensive agricultural system than pre-TBJ eruption western and central El Salvador, this could suggest an order of a quarter of a million people perished as a consequence of the TBJ eruption. The recurrence of rainy season lahars and basic challenges to food production likely hampered resettlement of proximal to medial regions around the caldera for some decades. Future archaeological, palynological and studies of other proxies may yet shed light on the scale of the human catastrophe as well as the coping strategies that may have conferred resilience and aided demographic, political and economic recovery.

\subsubsection{The post-TBJ maya refugee diaspora and future research directions}

While many of the TBJ eruption survivors would have perished as they fled the $\sim 20,000 \mathrm{~km}^{2}$ region left uninhabitable by the deep tephra fall deposits (Fig. 10) because of post-eruption disease outbreaks and because they could not reach food and clean water soon enough, some percentage of them would have reached areas where they were safe from Ilopango's direct life-limiting effects. According to our paleodemographic estimates, these refugees may have num- 

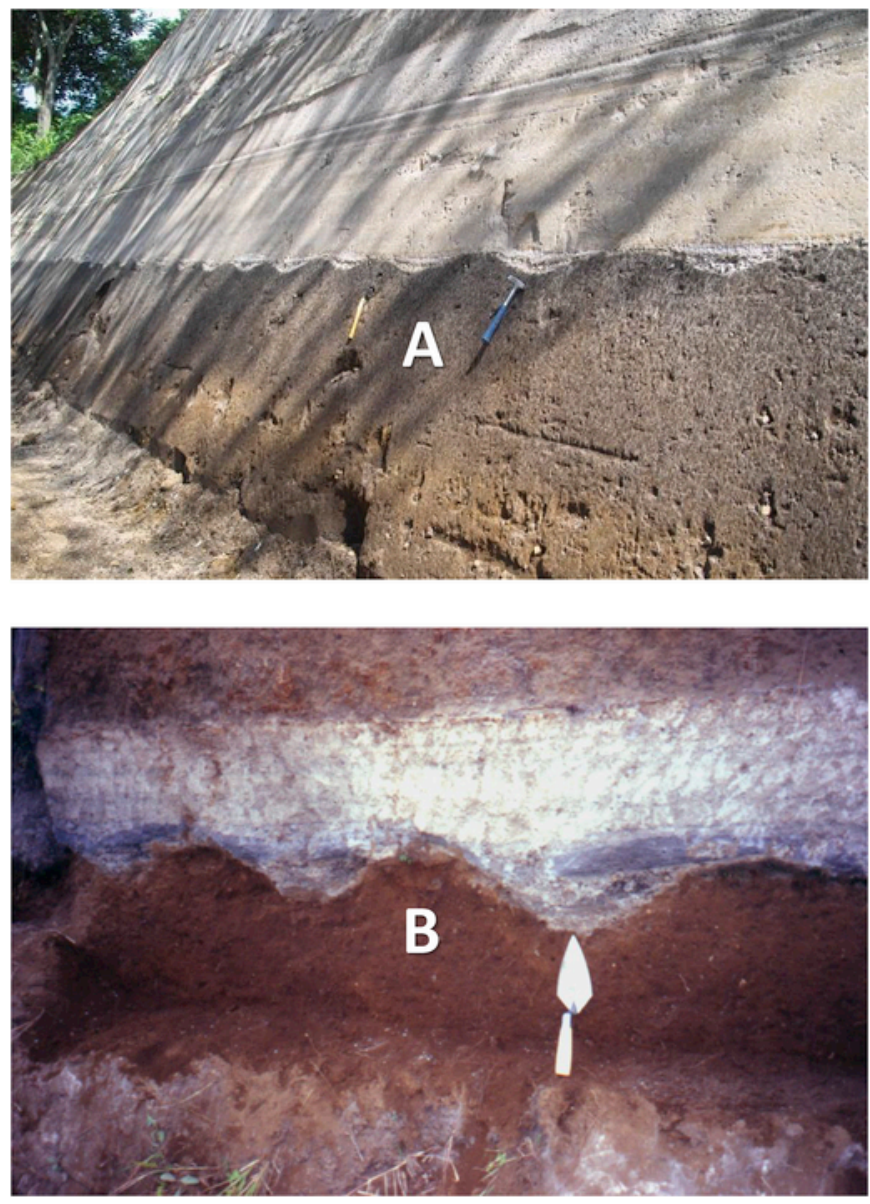

Fig. 12. High performance milpa agricultural fields buried under: A) the ca. $540 \mathrm{CE}$ Ilopango tephra; and B) the ca. 830 BCE Cuzcátan (Plan de la Laguna) tephra. Photos courtesy of S.K. and R.D.

bered in excess of 100,000 . Where the survivors went remains unknown. It has been postulated - based primarily on ceramic affinities - that many of the survivors would have fled to the north to major Mayan centers like Kaminaljuyú and Copán (Dull et al., 2001; Earnest, 1999).

We now know that both the Kaminaljuyú region (Lohse et al., 2018) and Copán (McNeil et al., 2010) received a light dusting $(<5 \mathrm{~cm})$ of TBJ ash fall, but the food-production capacity of these areas was likely not adversely affected for more than a single growing season; it might even have improved with minor tephra inputs. Still, we expect that the psychological impacts of the event arising from the fallout tephra, the daytime darkness, the sounds of the eruption, in addition to the consequences of coping with a large influx of refugees, would have challenged the belief systems and the political organization of these proximal Mayan polities. Many more polities throughout Mesoamerica experienced profound changes during this period and continuing throughout the end of the 6th Century CE, including sites in the southern Maya lowlands: Quirigua, Caracol, Ceibal and Tikal (Fig. 10) (Ashmore, 1984; Culbert, 1988; Dahlin and Chase, 2014; Robichaux, 2000; Willey, 1982).

Although there is a pronounced reduction in dated stelae during the "Maya Hiatus" from circa 534-593 CE (Culbert, 1988; Willey, 1982), Maya hieroglyphic texts and calendrical inscriptions presumably would have recorded some of these events. The hieroglyphic text on the Ante Step at Copán has already provided some tantalizing evidence for the impact of the TBJ eruption on this important Mayan center. One theory developed from this text is that the ceremonial center of Copán (Honduras) could have been temporarily abandoned because of fears and political destabilization related to the TBJ eruption sometime before 24 August $540 \mathrm{CE}$ and resettled by sometime in 542 CE (Tokovinine, 2017). The Ante Step has been referred to as, "k'anal ehb"' or "the yellow glorious step," (Law, 2006) which might also be a reference to the connection with light-colored TBJ tephra that fell on it.

Strontium isotope analysis of human bones (Hodell et al., 2004) also holds much promise for reconstructing the diaspora of TBJ refugees from the southeastern Maya region. Several commoner burials from this Early Classic time-period in the Copán archaeological zone have already been identified as people originating from the "volcanic highlands" and migrating as adults to Copán (Price et al., 2014), which is consistent with the TBJ refugee hypothesis. Future research on skeletal remains holds the promise of yielding a more nuanced understanding of post-TBJ Maya demographic shifts that resulted when so many refugees were fleeing the barren and geomorphologically dynamic lahar-prone landscapes of El Salvador, southeastern Guatemala and southern Honduras in the aftermath of the eruption.

\section{Summary and conclusions}

We have presented new geochronological and geological evidence to demonstrate that the TBJ eruption of Ilopango volcano in El Salvador is the only known 6th century eruption anywhere in the world that could explain the bipolar ice core sulfate deposit of $540 \mathrm{CE}$ and thus it is implicated as a primary contributor to the well-documented northern hemisphere cooling from 540 to 550 CE. Regionally, the 539/540 CE eruption profoundly influenced Mayan demography, economic patterns, and political structures; globally, the combined climatic effects of the early 6th century eruptions contributed to a (re)shaping of world history (Arjava, 2005; Baillie, 1999; Keys, 2000). While the identity of the Northern Hemisphere eruption in circa 536 CE remains unknown (Büntgen et al., 2016), the identification of the tropical 6th century eruption should provide new opportunities to evaluate climate model simulations of the impact of explosive volcanic eruptions (LeGrande et al., 2016) and to more precisely examine the role of the Ilopango TBJ eruption in the cultural history of Mesoamerica and the world.

\section{Author contributions}

R.D., J.S., S.K, K.A. and A.F. designed the study. R.D. and P.A. excavated and collected subfossil tree samples. S.K, A.F. and R.D. collected and sampled TBJ tephra from marine and lake sediment cores. S.K., W.H. and R.D. collected and measured terrestrial TBJ tephra deposits. A.F. and S.K. recorded and described the proximal eruptive sequence field geology. K.A., J.S. and R.D. processed and incrementally sampled subfossil trees for $14 \mathrm{C}$ analysis. Ring counts on the El Mico tree samples were done by K.A. and J.S. All AMS radiocarbon sampling and lab processing was performed by J.S. at the Keck C.C.A.M.S. Laboratory. D.W., S.K., and A.F. carried out I.C.P.-M.S. and electron microprobe analyses of tephra samples. Bayesian age models were constructed by K.A. Erupted volume calculations and modeling were done by S.K. and A.F. The archaeological context and prehistoric demographic estimates for the Maya region were investigated by P.S. and R.D. Subfossil tree identifications were carried out by M.W. The manuscript was written by R.D., J.S., S.K., K.A., P.S. and C.O. with input from all authors. 


\section{Data availability}

All primary data used in this study can be found in the Supplementary Data Section (Tables S-1, Tables S-2, Tables S-3). Any additional data requests should be made to the corresponding author.

\section{Declarations of interest}

None.

\section{Acknowledgements}

We thank Willie Scott, Jason Curtis, and Mark Brenner for sending us tephra samples from suspected TBJ deposits; National Director of Cultural Patrimony of El Salvador Arq. Gustavo Milán, Edgar Cabrera, and Fundación Nacional de Arqueología de El Salvador for support with fieldwork by RD and PA in El Salvador. This research was supported by the United States Geological Survey National Cooperative Geologic Mapping and Climate Research and Development Programs. SK and AF acknowledge funding by SFB 574 from the Deutsche Forschungsgemeinschaft. KA acknowledges funding from NOAA Grant NA18OAR4310420. RD acknowledges support from the University of Texas Jackson School of Geosciences, Social Sciences Research Council, and EOne Television (Toronto, Ontario, Canada). CO receives support from the NERC Center for Observation and Modeling of Earthquakes, Volcanoes and Tectonics.

\section{Appendix A. Supplementary data}

Supplementary data to this article can be found online at https:// doi.org/10.1016/j.quascirev.2019.07.037.

\section{References}

Alloway, B.V., Andreastuti, S., Setiawan, R., Miksic, J., Hua, Q., 2017. Archaeological implications of a widespread 13th Century tephra marker across the central Indonesian Archipelago. Quat. Sci. Rev. 155, 86-99.

Amaroli, P., Dull, R., 1999. Milpas prehispánicas en El Salvador (Prehispanic corn fields in El Salvador). Proceedings of the XII Simposio de Investigaciones Arqueológicas en Guatemala 1998, 639-650.

Anchukaitis, K.J., Evans, M.N., 2010. Tropical cloud forest climate variability and the demise of the Monteverde golden toad. Proc. Natl. Acad. Sci. 10.1073/ pnas.0908572107

Andrews, E.W., 1976. The Archaeology of Quelepa, El Salvador. Middle American Research Institute, Tulane University.

Arjava, A., 2005. The mystery cloud of 536 CE in the Mediterranean sources. Dumbart. Oaks Pap. 59, 73-94.

Ashmore, W., 1984. Quirigua archaeology and history revisited. J. Field Archaeol. 11, 365-386.

Ashmore, W., 2014. Practices of Spatial Discourse at Quelepa, the Maya and Their Central American Neighbors. 45-75, Routledge.

Baillie, M.G., 1994. Dendrochronology raises questions about the nature of the AD 536 dust-veil event. Holocene 4, 212-217.

Baillie, M.G., 1999. Exodus to Arthur: Catastrophic Encounters with Comets. BT Batsford Limited.

Baillie, M.G., 2008. Proposed re-dating of the European ice core chronology by seven years prior to the 7th century AD. Geophys. Res. Lett. 35 .

Barras, C., 2014. AD 536: the year that winter never ended. New Scientist 221, 34-38

Black, K., 1983. The Zapotitan Valley Archaeological Survey. Archeology and Volcanism in Central America: the Zapotitan Valley of El Salvador. 62-97.

Breeze, A., 2016. Arthur's battles and the volcanic winter of 536-37. North. Hist. 53, 161-172.

Brienen, R.J., Zuidema, P.A., 2005. Relating tree growth to rainfall in Bolivian rain forests: a test for six species using tree ring analysis. Oecologia 146, 1.

Büntgen, U., Myglan, V.S., Ljungqvist, F.C., McCormick, M., Di Cosmo, N., Sigl, M., Jungclaus, J., Wagner, S., Krusic, P.J., Esper, J., 2016. Cooling and societal change during the late Antique little ice age from 536 to around 660 AD. Nat. Geosci. 9, 231-236.
Collins, B.D., Dunne, T., 1986. Erosion of tephra from the 1980 eruption of mount st. Helens. Geol. Soc. Am. Bull. 97, 896-905.

Culbert, T.P., 1988. Political history and the decipherment of Maya glyphs. Antiquity $62,135-152$.

Dahlin, B.H., Chase, A., 2014. A tale of three cities: effects of AD 536 event on the lowland Maya heartland. In: Iannone, G. (Ed.), The Great Maya Droughts in Cultural Context: Case Studies in Resilience and Vulnerability. pp. 127-155.

Devine, J., Sigurdsson, H., Davis, A., Self, S., 1984. Estimates of sulfur and chlorine yield to the atmosphere from volcanic eruptions and potential climatic effects. J. Geophys. Res.: Solid Earth 89, 6309-6325.

Dull, R.A., 2004. Lessons from the mud, lessons from the Maya: paleoecological records of the Tierra Blanca joven eruption. GSA (Geol. Soc. Am.) Spec. Pap. (Reg. Stud.) 375, 237-244.

Dull, R.A., 2006. The maize revolution: a view from El Salvador. In: Staller, J.E., Tykot, R.H., Benz, B.F. (Eds.), Histories of Maize: Multidisciplinary Approaches to the Prehistory, Biogeography, Domestication, and Evolution of Maize. Academic Press, San Diego, CA, pp. 357-366.

Dull, R.A., 2007. Evidence for forest clearance, agriculture, and human-induced erosion in Precolumbian El Salvador. Ann. Assoc. Am. Geogr. 97, 127-141.

Dull, R.A., Southon, J.R., Sheets, P., 2001. Volcanism, ecology and culture: a reassessment of the Volcán Ilopango TBJ eruption in the southern Maya realm. Lat. Am. Antiq. 12, 25-44.

Dull, R., Southon, J., Kutterolf, S., Freundt, A., Wahl, D., Sheets, P., 2010. Did the TBJ Ilopango eruption cause the AD 536 event?. AGU Fall Meeting Abstracts 1, 2370 .

Earnest, H., 1999. A Reappraisal of the Ilopango Volcanic Eruption in Central El Salvador, Anthropology. Harvard University, Cambridge, Massachussetts.

Espíndola, J., Macías, J., Tilling, R., Sheridan, M., 2000. Volcanic history of El Chichón volcano (chiapas, Mexico) during the Holocene, and its impact on human activity. Bull. Volcanol. 62, 90-104.

Ferris, D.G., Cole-Dai, J., Reyes, A.R., Budner, D.M., 2011. South Pole ice core record of explosive volcanic eruptions in the first and second millennia $\mathrm{AD}$ and evidence of a large eruption in the tropics around 535 AD. J. Geophys. Res.: Atmosphere 1984-2012, 116.

Fierstein, J., Nathenson, M., 1992. Another look at the calculation of fallout tephra volumes. Bull. Volcanol. 54, 156-167.

Fowler, W.R., 1988. La población nativa de El Salvador al memento de la conquista española (The native population of El Salvador at the moment of the Spanish Conquest). Mesoamerica 15, 79-116.

Fowler, W.R., Earnest, H.H., 1985. Settlement patterns and prehistory of the paraiso basin of El Salvador. Journal of Filed Archaeology 12, 19-32.

Freundt, A., Grevemeyer, I., Rabbel, W., Hansteen, T.H., Hensen, C., Wehrmann, H., Kutterolf, S., Halama, R., Frische, M., 2014. Volatile (H2O, CO2, Cl, S) budget of the Central American subduction zone. Int. J. Earth Sci. 103, 2101-2127.

Galimberti, M., Ramsey, C.B., Manning, S.W., 2004. Wiggle-match dating of tree-ring sequences. Radiocarbon 46, 917-924.

Gautier, E., Savarino, J., Hoek, J., Erbland, J., Caillon, N., Hattori, S., Yoshida, N., Albalat, E., Albarede, F., Farquhar, J., 2019. 2600-years of stratospheric volcanism through sulfate isotopes. Nat. Commun. 10, 466.

Gill, R.B., 2000. The Great Maya Droughts: Water, Life, and Death. UNM Press.

Gran, K.B., Montgomery, D.R., Halbur, J.C., 2011. Long-term elevated post-eruption sedimentation at Mount Pinatubo, Philippines. Geology 39, 367-370.

Gunn, J.D., 2000. The years without summer: tracing AD 536 and its aftermath, British Archaeological Reports

Hammer, C.U., Clausen, H.B., Dansgaard, W., 1980. Greenland ice sheet evidence of post-glacial volcanism and its climatic impact. Nature 288, 230.

Harper, K., 2017. The Fate of Rome: Climate, Disease, and the End of an Empire. Princeton University Press.

Hart, W., Steen-McIntyre, V., 1983. Tierra Blanca joven tephra from the AD 260 eruption of Ilopango caldera. In: Sheets, P.D. (Ed.), Archaeology and Volcanism in Central America. University of Texas Press, Austin, Texas, pp. 14-34.

Helama, S., Arppe, L., Uusitalo, J., Holopainen, J., Mäkelä, H.M., Mäkinen, H., Mielikäinen, K., Nöjd, P., Sutinen, R., Taavitsainen, J.-P., 2018. Volcanic dust veils from sixth century tree-ring isotopes linked to reduced irradiance, primary production and human health. Sci. Rep. 8, 1339.

Hodell, D.A., Quinn, R.L., Brenner, M., Kamenov, G., 2004. Spatial variation of strontium isotopes $(87 \mathrm{Sr} / 86 \mathrm{Sr})$ in the Maya region: a tool for tracking ancient human migration. J. Archaeol. Sci. 31, 585-601.

Hunt, J.B., Hill, P.G., 2001. Tephrological implications of beam size-sample-size effects in electron microprobe analysis of glass shards. J. Quat. Sci.: Published for the Quaternary Research Association 16, 105-117.

Johnston, K.J., 2003. The intensification of pre-industrial cereal agriculture in the tropics: boserup, cultivation lengthening, and the Classic Maya. J. Anthropol. Archaeol. 22, 126-161.

Keys, D., 2000. Catastrophe: an Investigation into the Origins of the Modern World. Ballantine Books.

Kitamura, S., 2010. Two Radiocarbon Dates for the TBJ Tephra from Ilopango Caldera, El Salvador. Bulletin of the Faculty of Social Work, vol. 10, Hirosaki Gakuin University, 24-28. 
Klawonn, M., Houghton, B.F., Swanson, D.A., Fagents, S.A., Wessel, P., Wolfe, C.J., 2014. Constraining explosive volcanism: subjective choices during estimates of eruption magnitude. Bull. Volcanol. 76, 793.

Kutterolf, S., Freundt, A., Perez, W., 2008. Pacific offshore record of plinian arc volcanism in Central America: 2. Tephra volumes and erupted masses. Geochem. Geophys. Geosyst. 9.

Kutterolf, S., Freundt, A., Burkert, C., 2011. Eruptive history and magmatic evolution of the 1.9 kyr Plinian dacitic Chiltepe Tephra from Apoyeque volcano in west-central Nicaragua. Bull. Volcanol. 73, 811-831.

Kutterolf, S., Hansteen, T.H., Freundt, A., Wehrmann, H., Appel, K., Krüger, K., Perez, W., 2015. Bromine and chlorine emissions from Plinian eruptions along the Central American Volcanic Arc: from source to atmosphere. Earth Planet. Sci. Lett. 429, 234-246.

Larsen, L.B., Vinther, B.M., Briffa, K.R., Melvin, T.M., Clausen, H.B., Jones, P.D., Siggaard-Andersen, M.L., Hammer, C.U., Eronen, M., Grudd, H., 2008. New ice core evidence for a volcanic cause of the AD 536 dust veil. Geophys. Res. Lett. 35

Lavigne, F., Degeai, J.-P., Komorowski, J.-C., Guillet, S., Robert, V., Lahitte, P., Oppenheimer, C., Stoffel, M., Vidal, C.M., Pratomo, I., 2013. Source of the great AD 1257 mystery eruption unveiled, Samalas volcano, Rinjani Volcanic Complex, Indonesia. In: Proceedings of the National Academy of Sciences, 201307520.

Law, D.A., 2006. A Grammatical Description of the Early Classic Maya Hieroglyphic Inscriptions, Anthropology. Brigham Young University.

LeGrande, A.N., Tsigaridis, K., Bauer, S.E., 2016. Role of atmospheric chemistry in the climate impacts of stratospheric volcanic injections. Nat. Geosci. 9, ngeo2771.

Lisi, C.S., Fo, M.T., Botosso, P.C., Roig, F.A., Maria, V.R., Ferreira-Fedele, L., Voigt, A.R., 2008. Tree-ring formation, radial increment periodicity, and phenology of tree species from a seasonal semi-deciduous forest in southeast Brazil. IAWA J. 29, 189-207.

Lohse, J.C., Hamilton, W.D., Brenner, M., Curtis, J., Inomata, T., Morgan, M., Cardona, K., Aoyama, K., Yonenobu, H., 2018. Late Holocene volcanic activity and environmental change in Highland Guatemala. Quat. Sci. Rev. 191, 378-392.

Macías, J., Capra, L., Arce, J., Espíndola, J., García-Palomo, A., Sheridan, M., 2008. Hazard map of El Chichón volcano, Chiapas, México: constraints posed by eruptive history and computer simulations. J. Volcanol. Geotherm. Res. 175, 444-458.

Mason, B.G., Pyle, D.M., Oppenheimer, C., 2004. The size and frequency of the largest explosive eruptions on Earth. Bull. Volcanol. 66, 735-748.

McKee, C.O., Baillie, M.G., Reimer, P.J., 2015. A revised age of AD 667-699 for the latest major eruption at Rabaul. Bull. Volcanol. 77, 1-7.

McNeil, C.L., Burney, D.A., Burney, L.P., 2010. Evidence disputing deforestation as the cause for the collapse of the ancient Maya polity of Copan, Honduras. Proc. Natl. Acad. Sci. 107, 1017-1022.

Mehringer, P.J., Sarna-Wojcicki, A.M., Wollwage, L.K., Sheets, P., 2005. Age and extent of the Ilopango TBJ tephra inferred from a Holocene chronostratigraphic reference section, Lago de Yojoa, Honduras. Quat. Res. 63, 199-205.

Metzner, D., Kutterolf, S., Toohey, M., Timmreck, C., Niemeier, U., Freundt, A., Krüger, K., 2014. Radiative forcing and climate impact resulting from SO2 injections based on a 200,000-year record of Plinian eruptions along the Central American Volcanic Arc. Int. J. Earth Sci. 103, 2063-2079.

Moreland, J., 2018. AD536-BACK TO NATURE?. Acta Archaeol. 89, 91-111.

Newfield, T.P., 2018. The Climate Downturn of 536-50, the Palgrave Handbook of Climate History. Springer, 447-493.

Nooren, C., Hoek, W.Z., Tebbens, L.A., Martin Del Pozzo, A., 2009. Tephrochronological evidence for the late Holocene eruption history of El Chichón volcano, Mexico. Geofis. Int. 48, 97-112.

Nooren, K., Hoek, W.Z., Van Der Plicht, H., Sigl, M., van Bergen, M.J., Galop, D. Torrescano-Valle, N., Islebe, G., Huizinga, A., Winkels, T., 2017. Explosive eruption of El Chichón volcano (Mexico) disrupted 6th century Maya civilization and contributed to global cooling. Geology 45, 175-178.

Oppenheimer, C., 2003. Climatic, environmental and human consequences of the largest known historic eruption: Tambora volcano (Indonesia) 1815. Prog. Phys Geogr. 27, 230-259.

Oppenheimer, C., 2011. Eruptions that Shook the World. Cambridge University Press

Pedrazzi, D., Sunye-Puchol, I., Aguirre-Díaz, G., Costa, A., Smith, V.C., Poret, M. Dávila-Harris, P., Miggins, D.P., Hernández, W., Gutiérrez, E., 2019, 81-102. The Ilopango Tierra Blanca joven (TBJ) eruption, El Salvador: volcano-stratigraphy and physical characterization of the major Holocene event of Central America. J. Volcanol. Geotherm. Res.377,

Price, T.D., Nakamura, S., Suzuki, S., Burton, J.H., Tiesler, V., 2014. New isotope data on Maya mobility and enclaves at Classic Copan, Honduras. J. Anthropol. Archaeol. 36, 32-47.

Pyle, D.M., 1989. The thickness, volume and grainsize of tephra fall deposits. Bull. Volcanol. 51, 1-15.

Pyle, D.M., 1995. Mass and energy budgets of explosive volcanic eruptions. Geophys Res. Lett. 22, 563-566.

Rampino, M.R., Self, S., Stothers, R.B., 1988. Volcanic winters. Annu. Rev. Earth Planet Sci. 16, 73-99

Ramsey, C.B., 1995. Radiocarbon calibration and analysis of stratigraphy: the OxCal program. Radiocarbon 37, 425-430.
Ramsey, C.B., 2009. Bayesian analysis of radiocarbon dates. Radiocarbon 51, 337-360.

Rapprich, V., Erban, V., Fárová, K., Kopačková, V., Bellon, H., Hernandez, W., 2010. Volcanic history of the conchagua Peninsula (eastern El Salvador). J. Geosci. 55, 95-112.

Rigby, E., Symonds, M., Ward-Thompson, D., 2004. A comet impact in AD 536?. Astron. Geophys. 45, 1.23-21.26.

Robichaux, H.R., 2000. The Maya Hiatus and the AD536 Atmospheric Event, the Years without Summer: Tracing AD 536 and its Aftermath. 45-53.

Robock, A., 2002. Volcanic Eruptions and Climate. Climate Change: Natural Forcing Factors for Climate Change Timescales 10-1 to 10-5 Years, vol. 38, 305.

Roig, F.A., Osornio, J.J.J., Diaz, J.V., Luckman, B., Tiessen, H., Medina, A., Noellemeyer, E.J., 2005. Anatomy of growth rings at the yucatán Peninsula. Dendrochronologia 22, 187-193.

Rose, W.I., Conway, M.F., Pullinger, C.R., Deino, A., McIntosh, W.C., 1999. An improved age framework for late Quaternary silicic eruptions in northern Central America. Bull. Volcanol. 61, 106-120.

Sadofsky, S.J., Portnyagin, M., Hoernle, K., van den Bogaard, P., 2008. Subduction cycling of volatiles and trace elements through the Central American volcanic arc: evidence from melt inclusions. Contrib. Mineral. Petrol. 155, 433-456.

Sáenz, F., Durán-Quesada, A.M., 2015. A climatology of low level wind regimes over Central America using a weather type classification approach. Front. Earth Sci. 3, 15 .

Sarna-Wojcicki, A., Bowman, H., Meyer, C., Russell, P., Woodward, M., McCoy, G. Rowe, J., Baedecker, P., Asaro, F., Michael, H., 1984. Chemical analyses, correlations, and ages of upper Pliocene and Pleistocene ash layers of east-central and southern California. United States Geological Survey Special Paper 1293, 663.

Schindlbeck, J.C., Kutterolf, S., Freundt, A., Eisele, S., Wang, K.L., Frische, M., 2018. Miocene to Holocene marine tephrostratigraphy offshore northern Central America and southern Mexico: pulsed activity of known volcanic complexes. Geochem. Geophys. Geosyst. 19, 4143-4173.

Scott, W., Gardner, C., Devoli, G., Alvarez, A., 2006. The AD 1835 eruption of Volcán Cosigüina, Nicaragua: a guide for assessing local volcanic hazards. GSA (Geol. Soc. Am.) Spec. Pap. (Reg. Stud.) 412, 167-187.

Self, S., 2006. The effects and consequences of very large explosive volcanic eruptions. Philos. Trans. R. Soc. Lond.: Mathematical, Physical and Engineering Sciences 364, 2073-2097.

Self, S., Gertisser, R., Thordarson, T., Rampino, M., Wolff, J., 2004. Magma volume, volatile emissions, and stratospheric aerosols from the 1815 eruption of Tambora Geophys. Res. Lett. 31

Sheets, P.D., 1979. Environmental and cultural effects of the Ilopango eruption in Central America. In: Sheets, P.D., Grayson, D.K. (Eds.), Volcanic Activity and Human Ecology. Academic Press, New York, pp. 525-564.

Sheets, P.D., 1982. Prehistoric agricultural systems in El Salvador. In: Flannery, K. (Ed.), Maya Subsistence. Academic Press, New York, pp. 99-117.

Sheets, P.D., 1983. Archaeology and Volcanism in Central America. University of Texas Press, Austin, 307.

Sheets, P., 2012. Responses to explosive volcanic eruptions by small to complex societies in ancient Mexico and Central America. Surviving Sudden Environmental Change 43-63

Sigl, M., Winstrup, M., McConnell, J., Welten, K., Plunkett, G., Ludlow, F., Büntgen, U., Caffee, M., Chellman, N., Dahl-Jensen, D., 2015, 543-549. Timing and climate forcing of volcanic eruptions for the past 2,500 years. Nature, 523

Simkin, T., Siebert, L., Blong, R., 2001. Volcano fatalities-lessons from the historica record. Science 291, 255-255.

Southon, J., Mohtadi, M., De Pol-Holz, R., 2013. Planktonic foram dates from the Indonesian arc: marine $14 \mathrm{C}$ reservoir ages and a mythical AD 535 eruption of Krakatau. Radiocarbon 55, 1164-1172.

Steier, P., Rom, W., 2000. The use of Bayesian statistics for $14 \mathrm{C}$ dates of chronologically ordered samples: a critical analysis. Radiocarbon 42, 183-198.

Steier, P., Rom, W., Puchegger, S., 2001. New methods and critical aspects in Bayesian mathematics for $14 \mathrm{C}$ calibration. Radiocarbon 43, 373-380.

Stoffel, M., Khodri, M., Corona, C., Guillet, S., Poulain, V., Bekki, S., Guiot, J., Luckman, B.H., Oppenheimer, C., Lebas, N., 2015, 784-788. Estimates of volcanic-induced cooling in the Northern Hemisphere over the past 1,500 years. Nat. Geosci. 8

Stothers, R.B., 1984a. The great Tambora eruption in 1815 and its aftermath. Science 224, 1191-1198

Stothers, R.B., 1984b. Mystery cloud of AD 536. Nature 307, 344-345.

Stuiver, M., Polach, H.A., 1977. Discussion reporting of 14 C data. Radiocarbon 19, 355-363.

Suñe-Puchol, I., Aguirre-Díaz, G.J., Dávila-Harris, P., Miggins, D.P., Pedrazzi, D., Costa, A., Ortega-Obregón, C., Lacan, P., Hernández, W., Gutiérrez, E., 2019. The Ilopango caldera complex, El Salvador: origin and early ignimbrite-forming eruptions of a graben/pull-apart caldera structure. J. Volcanol. Geotherm. Res. 371, $1-19$.

Tanguy, J.-C., Ribière, C., Scarth, A., Tjetjep, W., 1998. Victims from volcanic eruptions: a revised database. Bull. Volcanol. 60, 137-144. 
Tokovinine, A., 2017. Copan reloaded: a new look at the Ante step and its context. In: The 81st Annual Meeting of the Society for American Archaeology, Vancouver, British Columbia, Canada.

Toohey, M., Krüger, K., Sigl, M., Stordal, F., Svensen, H., 2016. Climatic and societal impacts of a volcanic double event at the dawn of the Middle Ages. Clim. Change $136,401-412$.

Tvauri, A., 2014. The impact of the climate catastrophe of 536-537 AD in Estonia and neighbouring areas. Est. J. Archaeol. 18, 30.

Vázquez, L., Renton, K., 2015. High density of tree-cavities and snags in tropical dry forest of western Mexico raises questions for a latitudinal gradient. PLoS One 10, e0116745.

Volland-Voigt, F., Bräuning, A., Ganzhi, O., Peters, T., Maza, H., 2011. Radial stem variations of Tabebuia chrysantha (Bignoniaceae) in different tropical forest ecosystems of southern Ecuador. Trees (Berl.) 25, 39-48.

Wallace, P.J., Gerlach, T.M., 1994. Magmatic vapor source for sulfur dioxide released during volcanic eruptions: evidence from Mount Pinatubo. Science 265, 497-499.
Willey, G.R., 1982. Maya archeology. Science 215, 260-267.

Williams, H., Meyer-Abich, H., 1955. Volcanism in the Southern Part of El Salvador, vol. 32, University of California Publications in Geological Sciences, 1-64.

Worbes, M., 1995. How to measure growth dynamics in tropical trees a review. IAWA J. 16, 337-351.

Worbes, M., 2002. One hundred years of tree-ring research in the tropics-a brief history and an outlook to future challenges. Dendrochronologia 20, 217-231.

Yang, F., Schlesinger, M.E., 2002. On the surface and atmospheric temperature changes following the 1991 Pinatubo volcanic eruption: a GCM study. J. Geophys. Res.: Atmosphere 107.

Zier, C.J., 1980. A Classic-period Maya agricultural field in western El Salvador. J. Field Archaeol. 7, 65-74.

Zier, C.J., 1983. The Ceren site: a Classic period Maya residence and agricultural field in the Zapotitàn Valley. In: Sheets, P.D. (Ed.), Archaeology and Volcanism in Central America. University of Texas Press, Austin, Texas, pp. 119-143. 